\title{
Q3/Q4 2019 Solar Industry Update
}

David Feldman, NREL Eric O'Shaughnessy, Clean Kilowatts Robert Margolis, NREL

February 18, 2020 


\section{Executive Summary}

- EIA estimates that $32 \%$ of new U.S. electric generating capacity in 2019 came from solar (20\% UPV and 12\% DPV).

- EIA expects 2020 and 2021 installations to far exceed these levels, with 18 GWAC in 2020 and 20 GWAC in 2021.

- In the first nine months of 2019, the United States installed 7.1 GWDC of PV - a 10\% increase over the same period in 2018.

- The United States installed approximately $704 \mathrm{MWh}(327 \mathrm{MW})$ of energy storage onto the electric grid in the first nine months of 2019up $65 \%$ y/y.

- It was reported, though not confirmed, that SolarReserve had ceased operations, leaving BrightSource Energy as the only remaining experienced U.S. CSP developer.

- Most U.S. utility-scale solar PPAs are now being signed for less than $\$ 40 / \mathrm{MWh}$.

- Performance of solar companies rebounded, on average, in Q3 2019 as the ASP of modules stabilized.

- 2.5 GW of PV cells were imported into the United States in 2019, along

A list of acronyms and abbreviations is available at the end of the presentation. with $18.6 \mathrm{GW}$ of modules. And the United States manufactured more than $600 \mathrm{MW}$ of thin-film modules.

- In Q3 2019, PV module and component prices fell to historical lows again, with multi- and mono c-Si module ASP falling to $\$ 0.20 / \mathrm{W}$ and $\$ 0.22 / \mathrm{W}$ in September respectively.

- Polysilicon prices also fell to historical lows, pushing manufacturers out of the market.

- U.S. multi- and mono c-Si module ASP were $41 \%$ and $69 \%$ higher than the global average.

- From 2018 to 2019, lithium-ion battery prices dropped $13 \%$.

- From January 2, 2015 to January 2, 2020 solar stocks, on average, did not appreciate, though they gained 70\% in 2019 and another 18\% in the first two weeks of February 2020.

- In 2019, global solar investment totaled approximately \$139B with $91 \%$ going to solar projects.

- U.S. solar investment totaled \$25 billion in 2019.

- As of February 2020 , there nearly 250,000 solar jobs in the United States-down $4 \%$ from the 2016 peak but up $2 \%$ y/y. 
1 State and Federal Updates

2 Global Solar Deployment

3 U.S. PV Deployment

4 PV System Pricing

5 Global Manufacturing

6 Component Pricing

7 Market Activity 
1 State and Federal Updates

\section{Global Solar Deployment}

\section{U.S. PV Deployment}

4 PV System Pricing

5 Global Manufacturing

6 Component Pricing

7 Market Activity
- In Q1 2020, the Rhode Island governor signed an executive order committing the state to $100 \%$ renewable electricity by 2030, joining 10 other states that have made similar commitments.

- In December 2019, FERC regulators directed PJM, the largest capacity market in the world, to set a minimum offer price rule (MOPR) for all new electric generation resources receiving subsidies, effectively creating a floor price for new resources to bid into the wholesale market. 


\section{phased down or out.}

- Several of the most important state-level incentive programs have phased down or out by program design, including the California Solar Initiative and the the NY-Sun rebate program.

- At least 18 states and Washington, D.C. continue to offer incentives such as up-front rebates, tax credits, productionbased incentives, and SRECs. ${ }^{1}$

- Furthermore, at least 26 states and Washington, D.C. exempt PV systems from property taxes, and at least 20 states exempt PV systems from sales taxes.
- Even where state-level incentives are no longer available, many utilities continue to offer PV incentives.

- In some cases, state policies are important motivators for utility-led PV incentive programs.

- For example, Xcel's Solar*Rewards program offers production-based incentives to customers in Colorado and Minnesota. The program is a way to help Xcel meet state-mandated PV procurement standards. 


\section{Up-front subsidies are still available in at least seven states.}

\begin{tabular}{lll}
\hline State & Rebate Amount & Restrictions \\
\hline Connecticut & $\begin{array}{l}\$ 0.463 / \mathrm{W} \text { for first } 10 \mathrm{~kW}, \\
\$ 0.4 / \mathrm{W} \text { above } 10 \mathrm{~kW}\end{array}$ & Limited to residential customer-owned systems \\
\hline Maryland & $\$ 1,000$ & $<20 \mathrm{~kW}$ \\
\hline New Hampshire & $\$ 0.2 / \mathrm{W}$ & $<10 \mathrm{~kW} ;$ maximum: lesser of $\$ 1,000$ or $30 \%$ of \\
& & system costs
\end{tabular}




\section{Personal tax credits are still available in at least nine states.}

\begin{tabular}{lll}
\hline State & Credit Amount & Restrictions \\
\hline Arizona & $25 \%$ of system cost & Residential customers; maximum: $\$ 1,000$ \\
\hline Hawaii & $35 \%$ of system cost & $\begin{array}{l}\text { Maximum: } \$ 5,000 \text { for residential, } \\
\$ 500,000 \text { for nonresidential }\end{array}$ \\
\hline lowa & $15 \%$ of system cost & Maximum: $\$ 5,000$ \\
\hline Massachusetts & $15 \%$ of system cost & Maximum: $\$ 1,000$ \\
\hline Montana & $\$ 500$ per individual, $\$ 1,000$ per household & Residential customers \\
\hline New York & $25 \%$ of system cost & $\begin{array}{l}\text { Residential customers }<25 \mathrm{~kW},<50 \mathrm{~kW} \text { for } \\
\text { cooperative housing associations; } \\
\text { maximum: } \$ 5,000\end{array}$ \\
& & $\begin{array}{l}\text { May not exceed } \$ 3,500 \text { or } 50 \% \text { of tax liability } \\
\text { per year (may be carried over for } 10 \text { years) }\end{array}$ \\
\hline South Carolina & $25 \%$ of system cost & $\begin{array}{l}\text { Maximum: } \$ 2,000 \text { for residential; } \$ 50,000 \\
\text { for commercial }\end{array}$ \\
\hline Utah & $\begin{array}{l}\text { Residential: } 25 \% \text { of system cost; } \\
\text { commercial: } 10 \%\end{array}$ & $\begin{array}{l}\text { Non-residential customers } \\
\text { Vermont }\end{array}$ \\
\hline
\end{tabular}




\section{Production-based incentives are still available in at least five states.}

\begin{tabular}{|c|c|c|}
\hline State & Incentive Amount & Restrictions \\
\hline Arizona & $\begin{array}{l}\text { Begins at } \$ 0.04 / \mathrm{kWh} \text { and declines } \\
\text { to } \$ 0.01 / \mathrm{kWh} \text { by } 10^{\text {th }} \text { year }\end{array}$ & $\begin{array}{l}\text { Nonresidential customers (>5 MW); maximum: } \$ 2 \\
\text { million/year }\end{array}$ \\
\hline Connecticut & $\$ 0.035 / \mathrm{kWh}$ & TPO residential systems $<20 \mathrm{~kW}$ \\
\hline Delaware & $\begin{array}{l}<30 \mathrm{~kW}: \$ 0.06 / \mathrm{kWh} \\
30-200 \mathrm{~kW}: \$ 0.09 / \mathrm{kWh} \\
200-2,000 \mathrm{~kW}: \$ 0.05 / \mathrm{kWh}\end{array}$ & $\begin{array}{l}\text { Rates subject to change based on prevailing SREC } \\
\text { prices for first } 10 \text { years; from years } 10 \text { to } 20 \text {, the rate } \\
\text { is fixed at } \$ 0.035 / \mathrm{kWh} \text {. }\end{array}$ \\
\hline Massachusetts & $\begin{array}{l}\text { Rates vary based on installation } \\
\text { characteristics. }\end{array}$ & $\begin{array}{l}<5,000 \mathrm{~kW} \text {; term limited to } 10 \text { years for systems }<25 \\
\mathrm{~kW} \text { and } 20 \text { years for larger systems }\end{array}$ \\
\hline Oregon & $\$ 0.005 / \mathrm{kWh}$ & Utility-scale systems (210 MW) \\
\hline
\end{tabular}




\section{SRECS}

- SRECs are a special type of productionbased incentive where the value of the incentive varies based on the supply and demand of PV in a given state.

- In many cases, PV customers can monetize their SRECs by selling them into utility procurement programs (e.g., Xcel Solar*Rewards).

- In eight states (listed at right), customers can sell their SRECs directly into SREC markets or work with a third party to monetize their SRECs.

States with Active SREC Markets

\begin{tabular}{lc}
\hline State & $\begin{array}{c}\text { Current SREC Price } \\
\text { (\$/MWh) }\end{array}$ \\
\hline Delaware & $33^{\mathrm{a}}$ \\
Illinois & $73^{\mathrm{b}}$ \\
Maryland & $73^{\mathrm{c}}$ \\
\hline Massachusetts & $312^{\mathrm{c}}$ \\
\hline New Jersey & $225^{\mathrm{c}}$ \\
\hline Ohio & $7^{\mathrm{c}}$ \\
\hline Pennsylvania & $40^{\mathrm{c}}$ \\
\hline Washington, D.C. & $430^{c}$ \\
\hline
\end{tabular}

a Based on weighted average 2019 SREC bid price reported by SRECDelaware

${ }^{b}$ Based on SREC price set by Illinois Power Agency as of June 2018 for systems $<10 \mathrm{~kW}$

c Based on current bid price reported by SRECTrade as of 12/12/2019 
- Production-based incentives, particularly SRECs, are generally more valuable than up-front rebates and tax credits.

- In New Jersey and Washington, D.C., productionbased incentives can offset about half the installed cost of a PV system, although the effective value of ongoing incentives depends on end-user discount rates.

- In TPO transactions, SRECs are monetized by the third-party company. Some research suggests that TPO installers do not necessarily pass the full value of SRECs through to end-use customers, such that the SREC values depicted in the previous slide may exaggerate the real effects of SRECs on end-user PV prices.
- Furthermore, it should be noted that SREC prices have historically been volatile. In key markets such as New Jersey, SREC prices can fluctuate by hundreds of dollars per megawatt-hour over the course of months because of policy changes and supply bottlenecks. (See Slide 50.)

- In New York, Rhode Island, and South Carolina, customers can offset at least $25 \%$ of up-front costs through up-front rebates and tax credits.

- The remaining up-front incentives (rebates and tax credits) have relatively minor impacts on installed prices. 


\section{Property Taxes}

- Increased property tax burdens may be hidden costs for PV adopters. However, at least 26 states and Washington, D.C. fully exempt PV systems from property taxation, and at least 3 other states assess PV systems at reduced property tax rates.

- The impact of property tax exemptions on adopter costs varies based on local property tax rates and policies, but the savings are potentially significant. Property tax rates generally range from $1 \%$ to $3 \% .{ }^{1} \mathrm{~A}$ typical residential PV customer may therefore save around $\$ 200-\$ 500 /$ year in property taxes in tax-exempt states.

\section{Sales Taxes}

- Sales tax rates in the states with PV sales tax exemptions range from $2.9 \%$ (Colorado) to $7.25 \%$ (California). ${ }^{2}$

- Based on a typical 6-kW residential PV system priced at $\$ 3 / \mathrm{W}$, this equates to avoided up-front costs of around $\$ 500-$ $\$ 1,300$. 
At least five states and Washington, D.C. have specific incentives for low-income adopters.

\begin{tabular}{|c|c|c|}
\hline State & Incentive(s) & Restrictions \\
\hline California & $\$ 3 / \mathrm{W}$ rebate & $1 \mathrm{~kW}$ to $5 \mathrm{~kW}$ \\
\hline Connecticut & $\begin{array}{l}\$ 0.11 / \mathrm{kWh} \text { for first } 10 \mathrm{~kW} \text { or up to } 100 \% \text { of annual } \\
\text { electricity usage, } \$ 0.055 / \mathrm{kWh} \text { beyond } 10 \mathrm{~kW} \text { or } 100 \% \text { of } \\
\text { annual electricity usage }\end{array}$ & TPO systems $<20 \mathrm{~kW}$ \\
\hline Illinois & $\begin{array}{l}\text { Customer bears no up-front costs and ongoing costs are } \\
\text { capped at } 50 \% \text { of the value of the generated energy. }\end{array}$ & Program capped at $\$ 7.5 \mathrm{M} /$ year \\
\hline Massachusetts & $\begin{array}{l}\text { Rates vary based on methodologies of the SMART } \\
\text { program, but low-income customers are eligible for } \\
\text { higher base compensation rates and volumetric adders. }\end{array}$ & $\begin{array}{l}<5,000 \mathrm{~kW} \text {; term limited to } 10 \\
\text { years for systems }<25 \mathrm{~kW}, 20 \\
\text { years for larger systems }\end{array}$ \\
\hline New York & $\begin{array}{l}\$ 0.8 / \mathrm{W} ; \text { a } \$ 0.4 / \mathrm{W} \text { adder is also available for systems } \\
\text { installed on multifamily housing. }\end{array}$ & $\begin{array}{l}\text { Single-family: }<10 \mathrm{~kW} \\
\text { Multi-family: }<50 \mathrm{~kW}\end{array}$ \\
\hline Washington, D.C. & Full system cost (up to $\$ 10,000$ )* & $3-4 \mathrm{~kW}$ \\
\hline
\end{tabular}




\section{Summary}

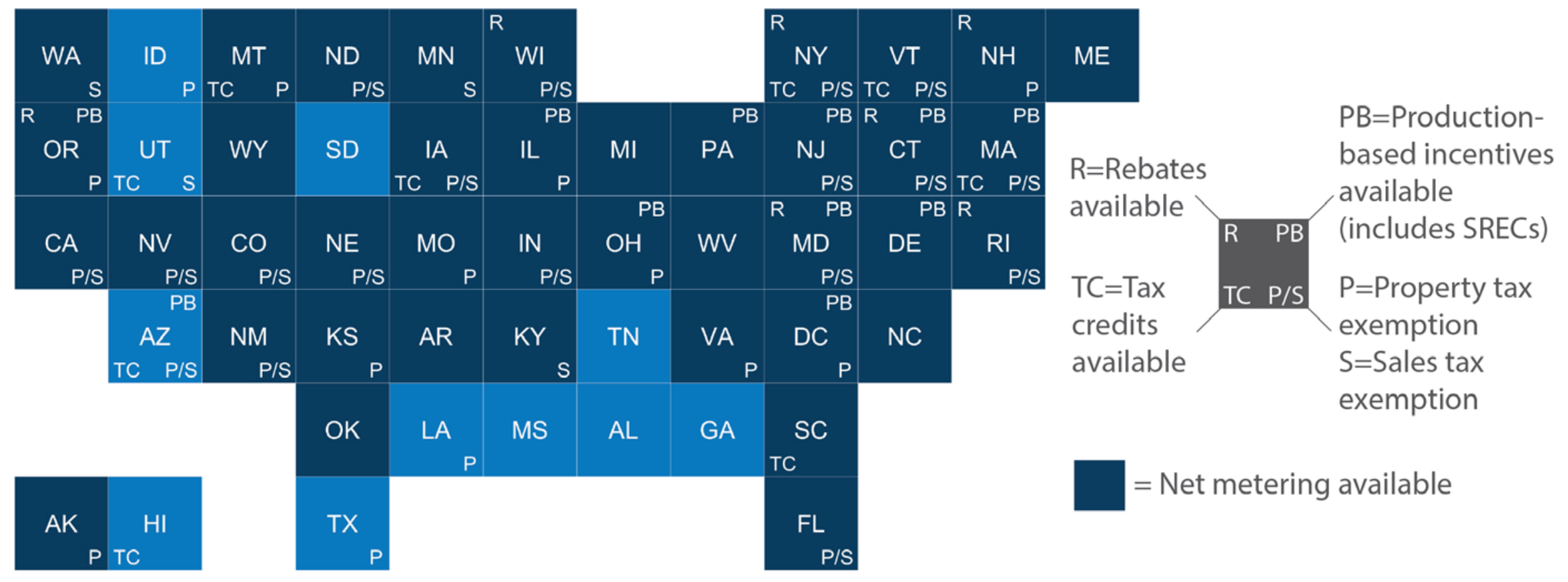


- In December 2019, FERC regulators directed PJM, the largest capacity market in the world, to set a minimum offer price rule (MOPR) for all new electric generation resources receiving subsidieseffectively creating a floor price for new resources to bid into the capacity market-by March 18, 2020.

- The FERC chairman believes renewables should compete today without subsidies or regulation, and that the subsidies distort the market.

- States, clean energy advocates, and market observers believe the new rule subverts the intended goals of the states (e.g. RPS targets) and have estimated it will raise market costs from $\$ 2.4$ billion-\$8.4 billion per year.

- If enacted, Illinois, Maryland and New Jersey are considering pulling out of the PJM market.

- FERC also made a similar ruling in late February 2020 on New York's power market, which affectively kept a floor price on renewable projects bidding into the NY-ISO capacity market.

- In the New York ruling, FERC narrowed exemptions on the buyer-side mitigation (BSM) market rules. BSM was established to prevent large electricity buyers from manipulating the market, bringing down overall pricing by also supplying a small amount of low-priced power. The rules subject these suppliers to an offer floor. They now also apply to suppliers who receive revenue from state-administered programs, such as RECs. 


\section{State and Federal Updates}

\section{Global Solar Deployment}

\section{U.S. PV Deployment}

\section{PV System Pricing}

\section{Global Manufacturing}

6 Component Pricing
- Spain, already the world's leading market in CSP installations, recently submitted a plan to the European Union, calling for the development of $5 \mathrm{GW}$ of CSP between 2021 and 2030.

- It was reported, though not confirmed, that SolarReserve had ceased operations, leaving BrightSource Energy as the only remaining experienced U.S. CSP developer.

- Given Spanish CSP plants' record of good production for over 10 years, financial institutions have started purchasing existing assets. 


\section{Global CSP Activity}

- Spain, already the world's leading market in CSP installations, recently submitted a plan to the European Union, calling for the development of $5 \mathrm{GW}$ of CSP between 2021 and 2030. As with other recent projects, the CSP plants would be designed to store energy during the day-complementing PV systems generating power- and produce power at night.

- Given Spanish CSP plants' record of good production for over 10 years, financial institutions have started purchasing existing assets.

- Terraform Power recently acquired 350 MW of projects and Credit Suisse purchased a 49\% stake in 250 MW of CSP capacity.

- CSP output in 2019 rose $17 \%$ and was $3.8 \%$ higher than the average for the last five years, signaling improved operations and maintenance efficiency for Spain's CSP fleet.

- In January 2020, Shanghai Electric completed the tower on the Noor Energy 1 CSP project in Dubai, which is set to be part of the largest CSP plant in the world.

- In November 2019, a fire broke out at Cerro Dominator, currently under construction as the first utility-scale CSP plant in Latin America. The fire was spotted at the top of the tower, which is similar to the location of a 2016 fire at the U.S. Ivanpah CSP project. 


\section{U.S. CSP Activity}

- It was reported, though not confirmed, that SolarReserve had ceased operations, leaving BrightSource Energy as the only remaining experienced U.S. CSP developer.

- The PPA from SolarReserve's Crescent Dunes project was canceled late last year by NV Energy because of missed performance guarantees.

- SolarReserve had also sold its foreign projects in Chile and Australia last year.

- U.S. CSP technology developer Heliogen achieved temperatures exceeding $1,000^{\circ} \mathrm{C}$ by improving the reflectiveness of its tower arrays.

- With generated heat at this temperature, CSP plants could replace fossil fuel plants for industrial process heat.

- Heliogen is trying to reach temperatures of $1,500^{\circ} \mathrm{C}$, which would allow it to make fuels such as hydrogen. 


\section{State and Federal Updates}

\section{Global Solar Deployment}

\section{U.S. PV Deployment}

4 PV System Pricing

5 Global Manufacturing

6 Component Pricing

7 Market Activity
- EIA estimates $32 \%$ of new U.S. electric generating capacity in 2019 came from solar (20\% UPV and $12 \%$ DPV).

- EIA expects 2020 and 2021 installations to far exceed these levels, with 18 GWAC in 2020 and 20 GWAC in 2021.

- In the first nine months of 2019, the United States installed 7.1 GWDC of PV-a $10 \%$ increase over the same period in 2018.

- The United States installed approximately 704 MWh (327 MW) of energy storage onto the electric grid in the first nine months of 2019-up 65\% y/y. 


\section{U.S. Generation Capacity Additions by Source: 2018 and Estimated 2019}

- EIA estimates the percentage of U.S. electric capacity additions from solar grew from $22 \%$ in 2018 to $32 \%$ in 2019 (20\% UPV and 12\% DPV). It is estimated that $39 \%$ of additions came from wind in 2019.

- Based on data through October 2019, solar capacity additions are expected to increase from 2018 installations by over 1 GWAC, y/y.

- Combined, EIA estimates more solar and wind was installed in 2019 than in any other year.

\section{U.S. Generation Capacity Additions}

(Total: $37.6 \mathrm{GW}$ )

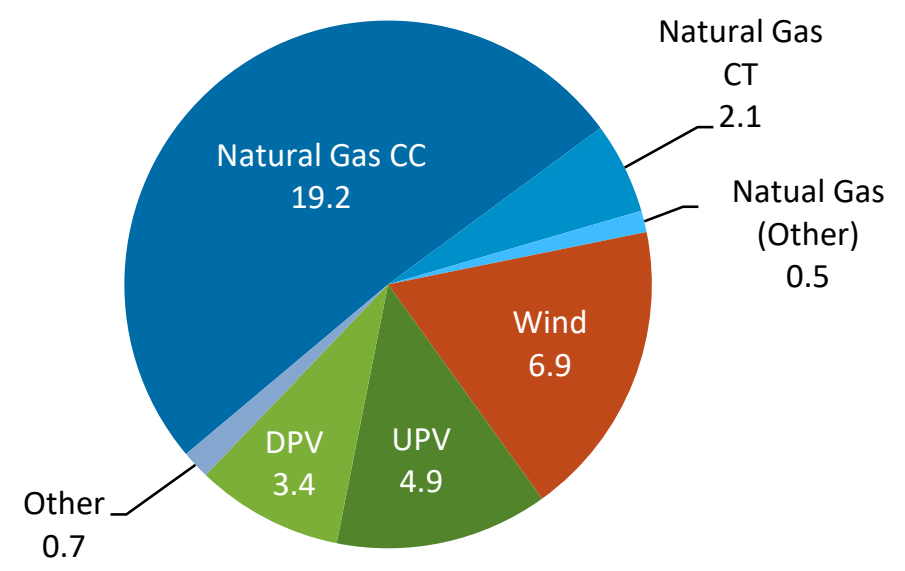

Sources: EIA “Preliminary Monthly Electric Generator Inventory. Solar: EIA "Electric Power Monthly" Table $6.1 ; 2018$ DPV estimate is estimated by multiplying January-October installations by $12 / 10$.
- Based on EIA data through October 2019, it is estimated that 30.3 GW of new electric generating capacity came online in 2019-down from 37.6 GWAC in 2018.

- 18.3 GW came online from January through October 2018, and another $12.0 \mathrm{GW}(40 \%)$ is estimated to have come online in November and December.

- 2019 annual wind and solar additions are expected to be second only to 2012 (wind) and 2016 (solar), when the wind and solar industry installed $13.3 \mathrm{GWAC}$ and $11.3 \mathrm{GWAC}$ in anticipation of an expiring PTC and ITC, respectively.

\section{Estimated 2019 U.S. Generation Capacity Additions} (Total: $\mathbf{3 0 . 3} \mathrm{GW}$ )

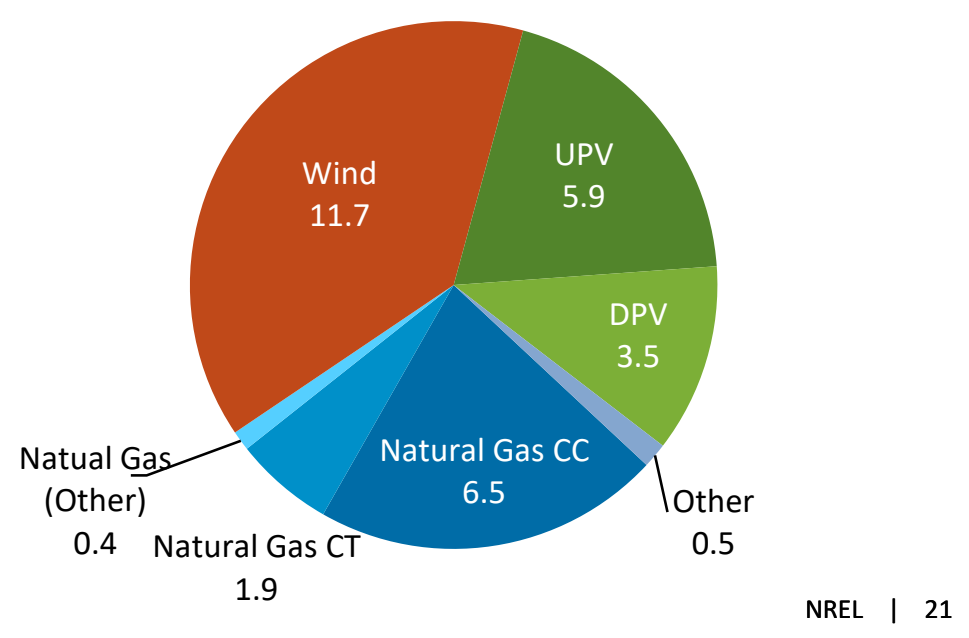




\section{EIA Estimated U.S. Wind and Solar Capacity Additions: 2018-2021}

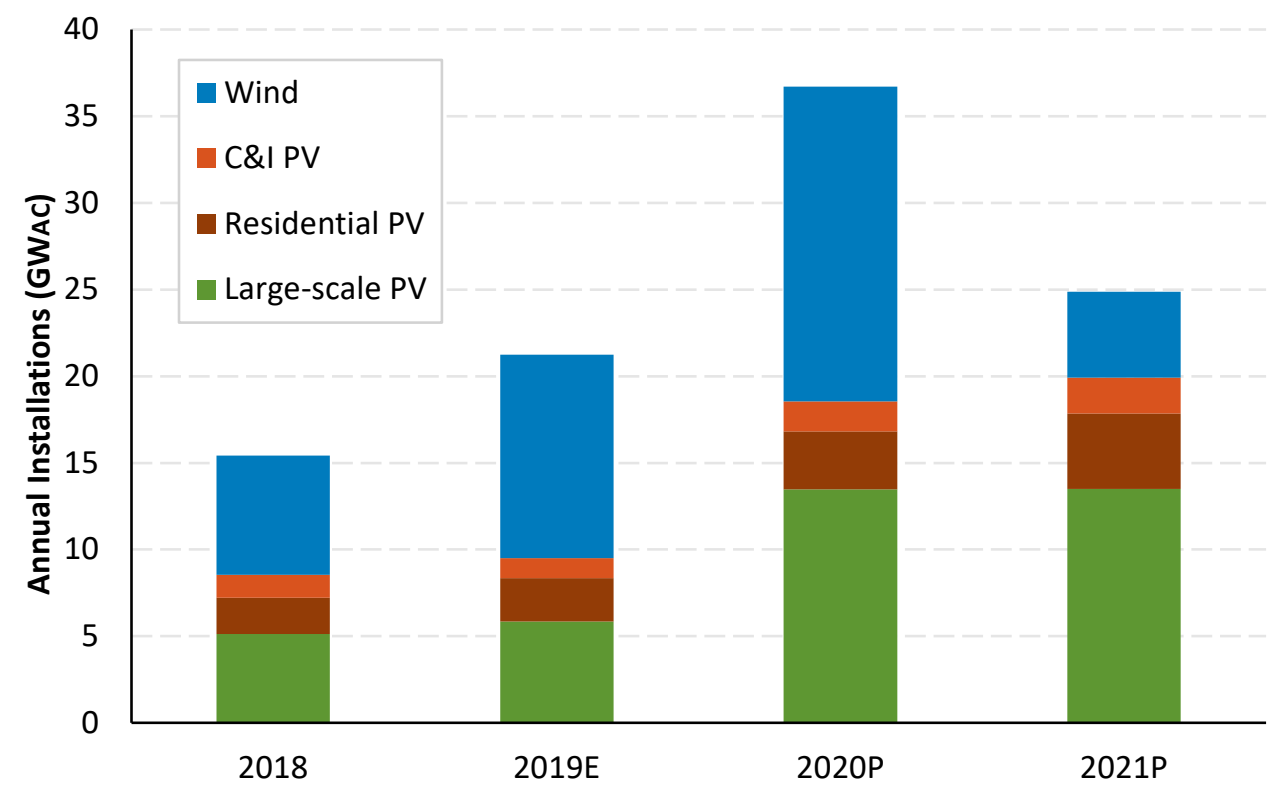

- While 2019 U.S. solar and wind installations collectively achieved record levels, EIA expects 2020 and 2021 installations to far exceed these levels, with $37 \mathrm{GWAC}$ in 2020 and 25 GWAC in 2021.

- Wind installations are projected to peak in 2020 with 18 GWAC.

- EIA estimates solar will install 20 GWAC in 2021, consisting of 13.5 GW of large-scale PV, 4.4 GW of residential and $2.1 \mathrm{GW}$ of commercial and industrial-scale PV.

- Wood Mackenzie reports more than 5 GWDC of announced Texas PV projects; while most have electric offtake agreements, Wood Mackenzie reports a growing number are being built as merchant projects to sell power directly into the ERCOT market.

- Over the summer of 2019, Texas energy prices hit $\$ 9,000 / \mathrm{MWh}$ several times.

- Wood Mackenzie also reports recent PPA prices ranging from $\$ 18 / \mathrm{MWh}$ to $\$ 35 / \mathrm{MWh}$. 


\section{Annual Energy Outlook}

- EIA's 2020 Annual Energy Outlook projects that renewable power will be the fastest-growing source of electricity over the next three decades, accounting for $38 \%$ of generation by 2050 , eclipsing natural gas after 2045.

- The previous version of the report, AEO2019, forecasted 31\% of generation would come from renewables and $39 \%$ from natural gas in 2050.

ב̇

\section{U.S. Electric Generation}

6,000

UPV

Wind

- Other

- Gas

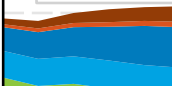

3,000

2,000

1,000

0

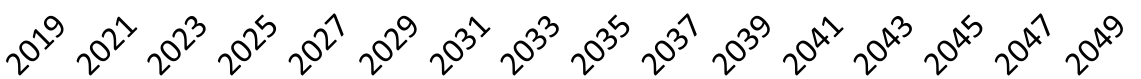

Other Renewables

Nuclear

coal
- "This shift has been strongly influenced by federal and state policies that help make renewables the fastest-growing source of electricity," EIA Administrator Linda Capuano said at an event in Washington, D.C.

- The report also noted that while coal and natural gas will drop, their levels will stabilize over the next decade as economically viable plants remain active.

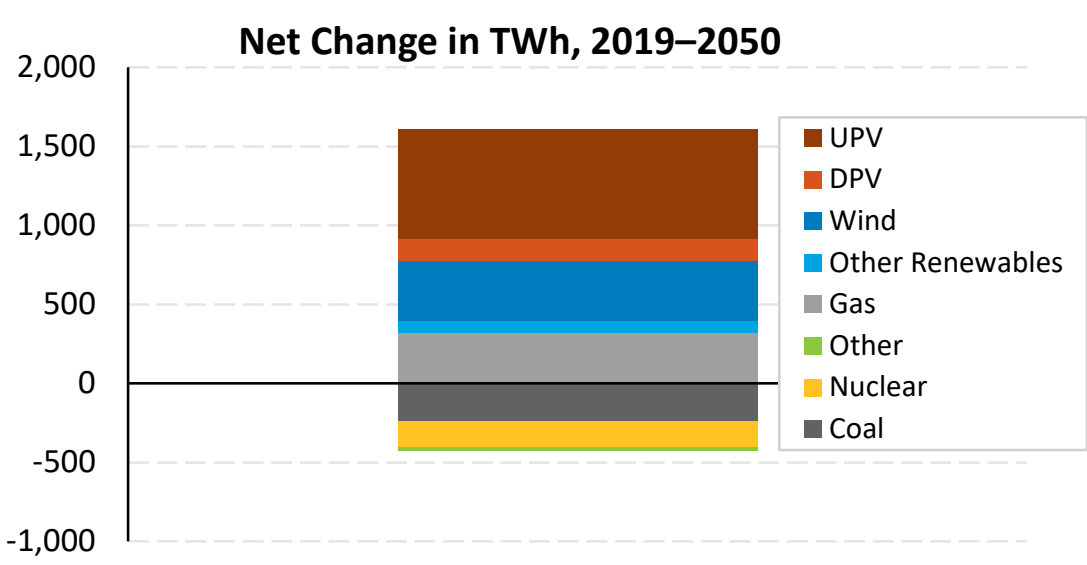




\section{Projections from Different Reports}

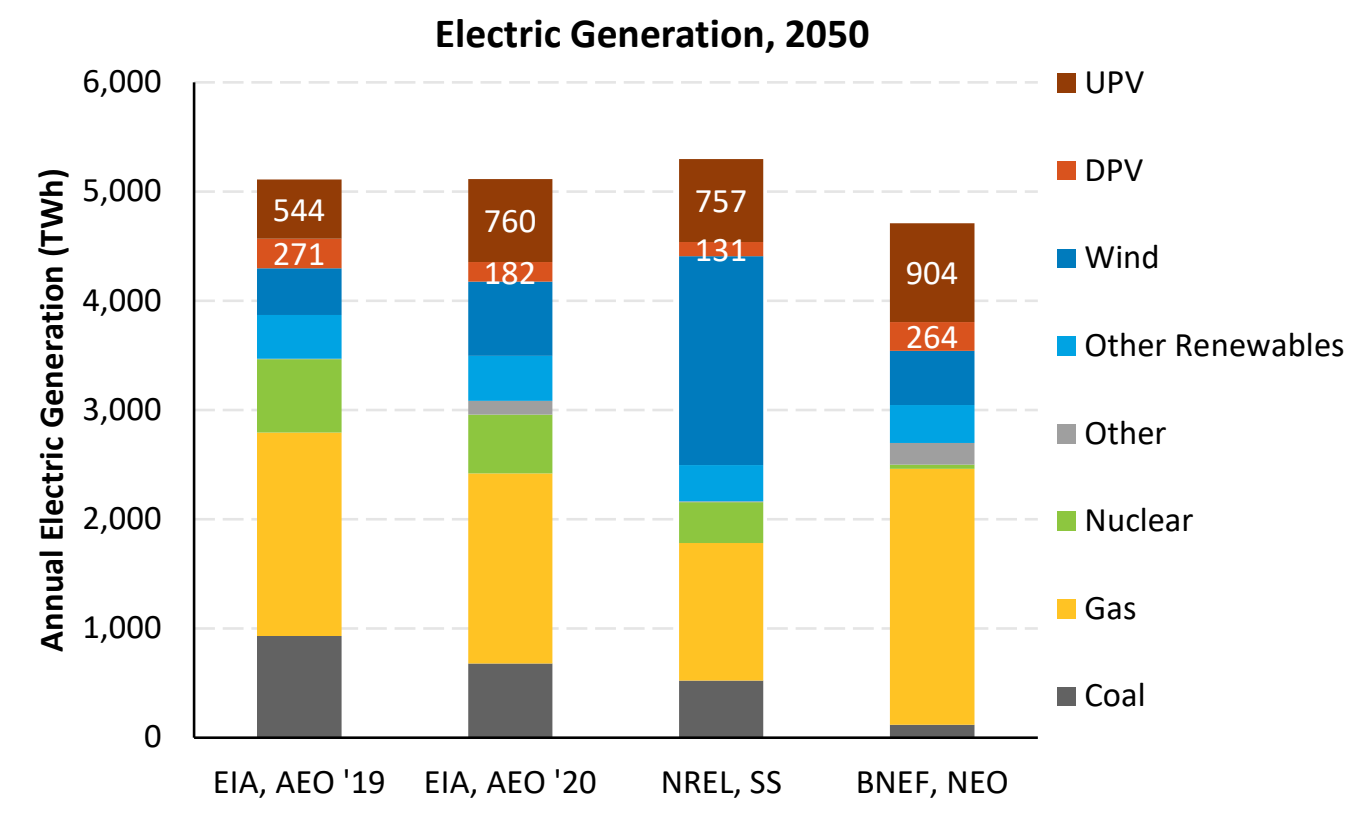

- The 2020 Annual Electricity Outlook reference-case projects $16 \%$ more electricity generation from solar than the 2019 version and 6\% greater than NREL's 2019 Standard Scenarios mid-case.

- However, the AEO 2020 is still 19\% less than BNEF's New Energy Outlook.

- Other variations exist within the analysis, with NREL projecting significantly more wind generation, while BNEF projecting significantly more generation from gas. 


\section{U.S. Installation Breakdown}

- In the first nine months of 2019, the United States installed 7.1 GWDC of PV - a 10\% increase over the same period in 2018.

- In Q3 2019, the residential PV market and 15 individual states hit all-time highs, as new markets compensated for low to flat growth from more mature markets.

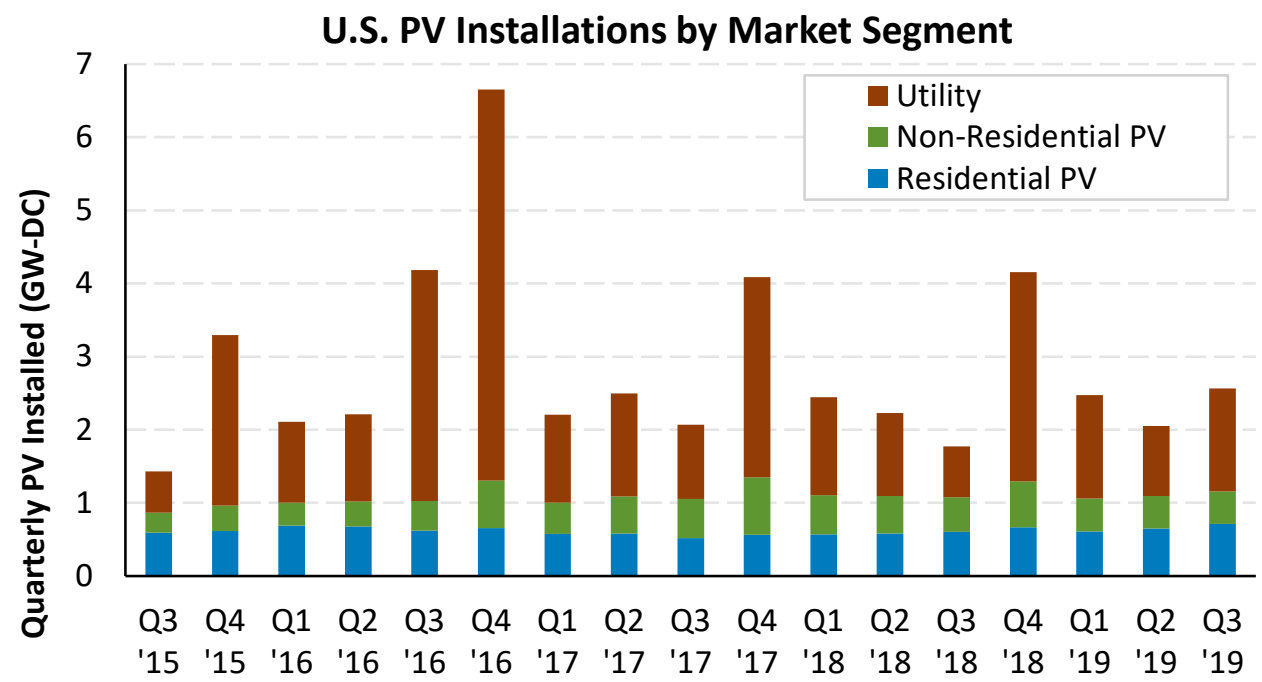

- Wood Mackenzie attributes some of California's residential growth to new-build homes and interest in solar, and solar-plus-storage, caused by dissatisfaction of electric utilities. Storage may also help future customers in the next few years as California is set to revise its net metering policy again.

- Conversely, the Northeast markets have slowed due to high levels of saturation of early adopter causing increased customer acquisition costs.

- California, Florida, the rest of the Southeast, and the Southwest, each installed more than 1 GWDC in the first nine months of 2019.

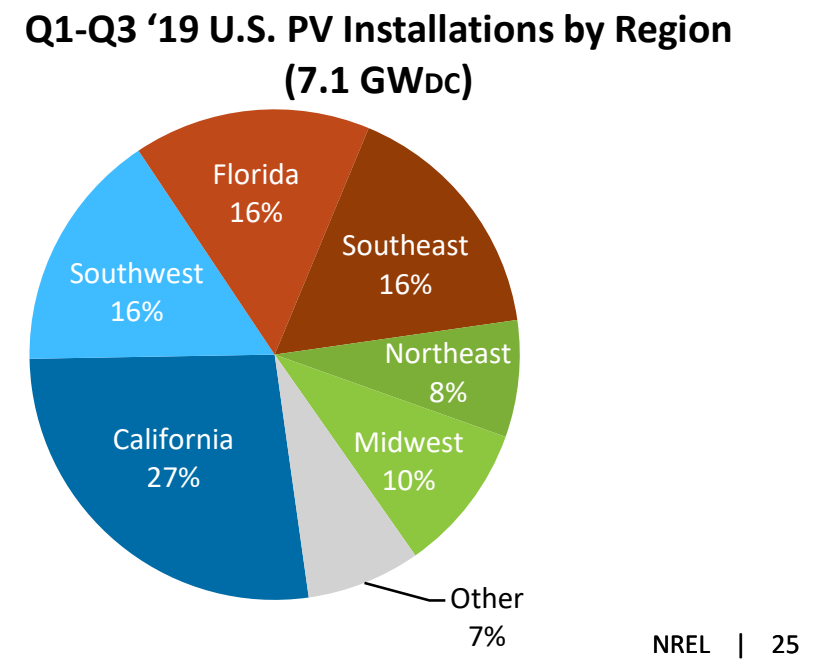




\section{U.S. Off-Site Corporate Solar PPAs}

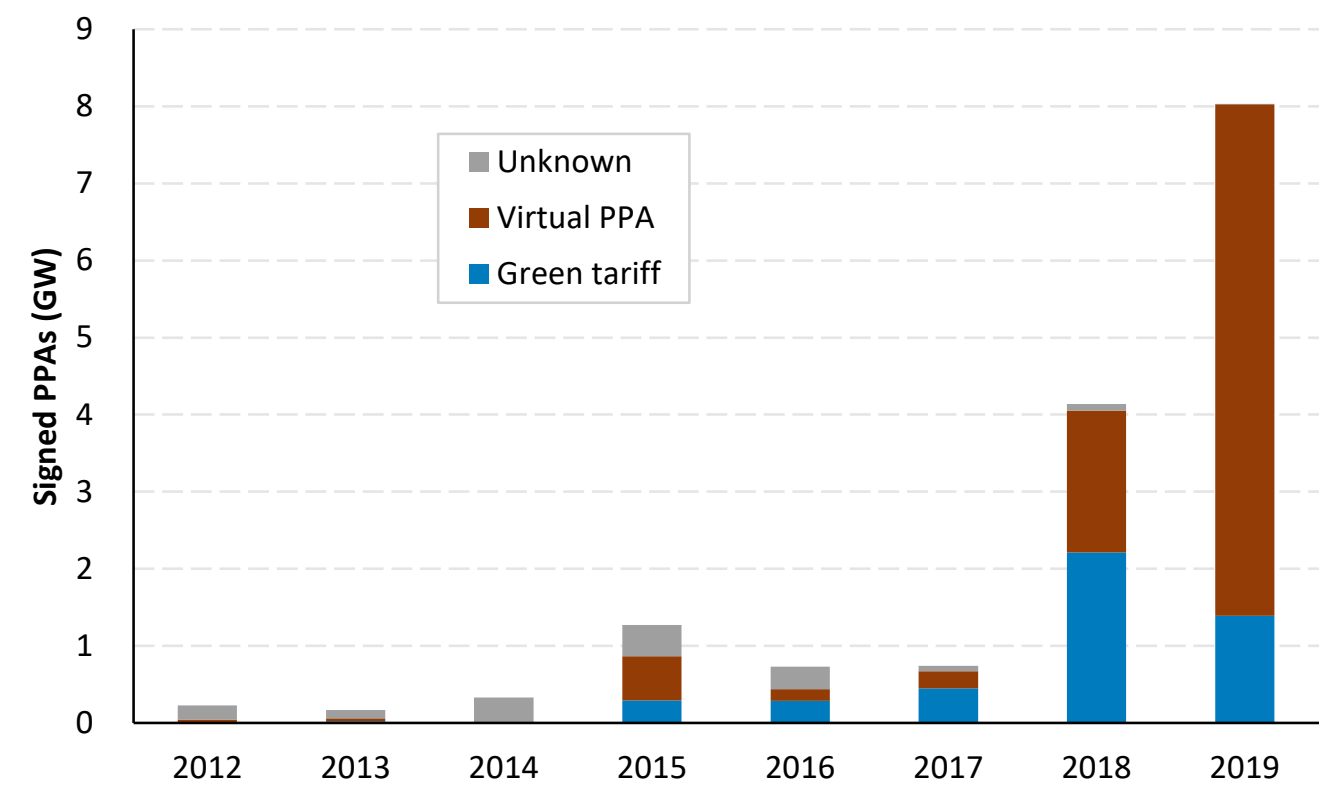

- Led by the tech industry, U.S. corporate solar contracts were up $80 \%$ in $2019, y / y$, with just over $8 \mathrm{GW}$.

- The United States represented approximately $84 \%$ of the global offsite corporate market in 2019, and solar represented approximately $51 \%$ of total offsite renewable PPAs in 2019.

- $83 \%$ of the 2019 U.S. solar contracts were in the form of virtual PPAs, with the remainder of from green tariffs.

- At the end of 2019, the leading five U.S. offsite corporate solar offtakers were Facebook, Google, Microsoft, Amazon, and Apple, with a collective $6.9 \mathrm{GW}$ of PPAs.

- Google signed more than 1.4 GW of offsite U.S. solar PPAs in 2019 alone. 


\section{Sunnova, Sunrun, Tesla, and Vivint Residential Market Share}

- Sunnova, Sunrun, and Vivint experienced $52 \%, 7 \%$, and $20 \%$ increases in installations in Q3 2019 respectively, y/y.

- Total Q3 2019 U.S. residential PV installations increased $18 \%, \mathrm{y} / \mathrm{y}$.

- Tesla sales were down $54 \%$ over the same period but up $48 \% \mathrm{Q} / \mathrm{Q}$.

- Tesla continues to focus on direct sales, while well over $75 \%$ of Sunnova, Sunrun, and Vivint sales still come from leases or PPAs.

- Despite lackluster PV sales, Tesla Powerwall system sales continue to grow, with more than $1.3 \mathrm{GWh}$ installed in the past year.

- In Q3 2019, Tesla installed 477 MWh of storage-a 99\% increase, $y / y$.

\section{Residential Installs}

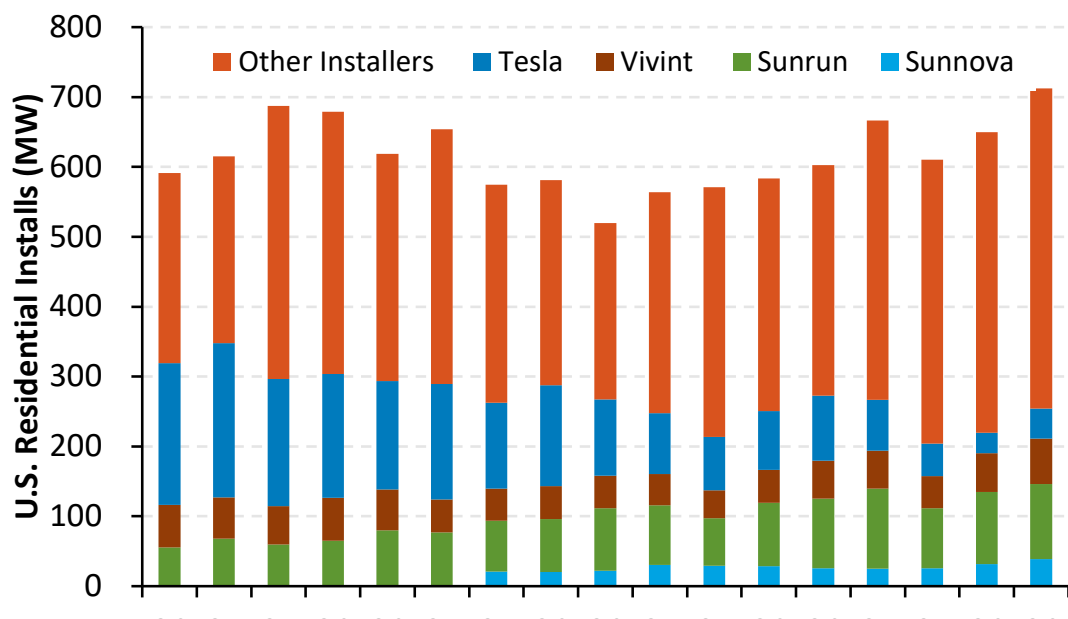

Q3 Q4 Q1 Q2 Q3 Q4 Q1 Q2 Q3 Q4 Q1 Q2 Q3 Q4 Q1 Q2 Q3 '15 '15 '16 '16 '16 '16 '17 '17' 17 '17 '18 '18 '18 '18 ' '18 '

Percent of Direct Sales / Loans

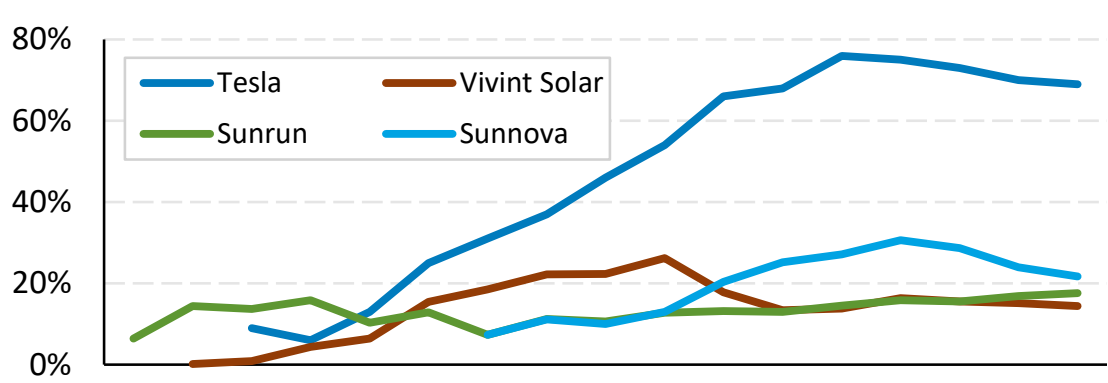

Q3 Q4 Q1 Q2 Q3 Q4 Q1 Q2 Q3 Q4 Q1 Q2 Q3 Q4 Q1 Q2 Q3

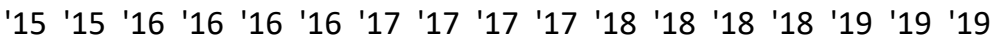




\section{Five New Things to Know from Utility-Scale Solar: 2019 Edition}

1. Areas with the highest solar penetration (CAISO and ISO-NE) were the only two markets where solar's "value factor" ${ }^{1}$ dipped below $100 \%$ (Chart 1 ).

2. As module prices have fallen, developers have increasingly oversized the DC array capacity relative to the $A C$ inverter capacity to enhance revenue and reduce output variability.

- Fixed-tilt PV has more to gain from a higher ILR than does tracking PV, with median 2018 ILR values of 1.41 and 1.31 respectively.

3. Utility-scale solar is increasingly built at lower-insolation sites (Chart 2), with fixed-tilt installations mostly in low-insolation/brown-field/landfill sites, or windy regions.

4. Tracking boosts net-capacity factors by up to $5 \%$ in high-insolation regions.

5. Only two of the seven ISOs (CAISO and ERCOT) currently report solar curtailment.

- Despite having a lower penetration ( $1 \%$ vs. 16\%), ERCOT had a higher curtailment rate $(6.7 \%)$ than CAISO (1.2\%) in 2018. ERCOT curtailment is mostly in a few projects caught on the wrong side of transmission congestion in West Texas.
Chart 1. Solar Value Factor $\square_{2012} \square_{2013}^{\text {Solar Value Factor (left axis) }} \square^{2014} \square^{2015} \square^{2016} \square_{2018}^{2018}$ $\circ \longleftarrow$ Solar Penetration (right axis)

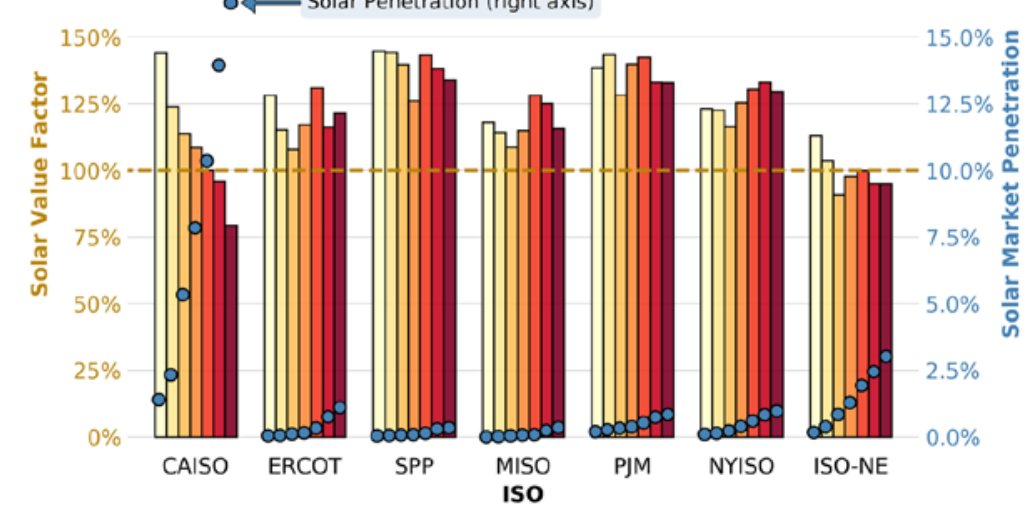

Chart 2. Median GHI over time

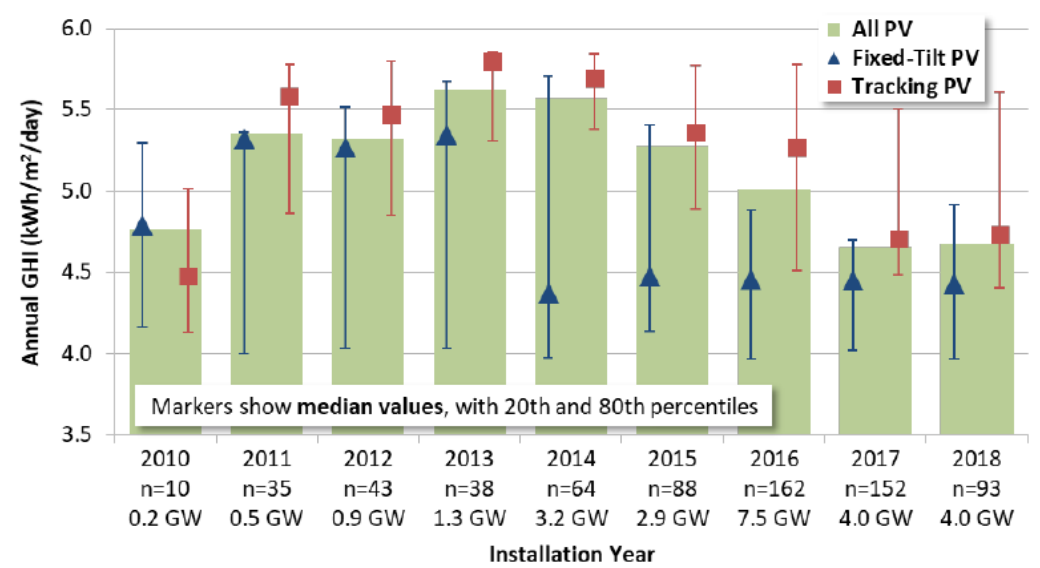

Source: Bolinger, M., J. Seel, and D. Robson. 2019. Solar Empirical Trends in Project Technology, Cost, Performance, and PPA Pricing in the United States: 2019 NREL | 30 Edition. Berkeley, CA: Lawrence Berkeley National Laboratory 


\section{State and Federal Updates}

\section{Global Solar Deployment}

\section{U.S. PV Deployment}

\section{PV System Pricing}

\section{Global Manufacturing}

6 Component Pricing
- The median installed price of PV has fallen by nearly $70 \%$ since 2010 , to $\$ 1.6 /$ WAC $(\$ 1.2 / W D C)$ in 2018.

- Most U.S. utility-scale solar PPAs are now being signed at less than $\$ 40 / \mathrm{MWh}$.

- In Q3 2019, totals costs for Vivint- and Sunrunbuilt systems were approximately $\$ 3.25 / \mathrm{W}-$ $\$ 3.50 / \mathrm{W}$. 


\section{Reported Price of Utility-Scale PV Projects Over Time}

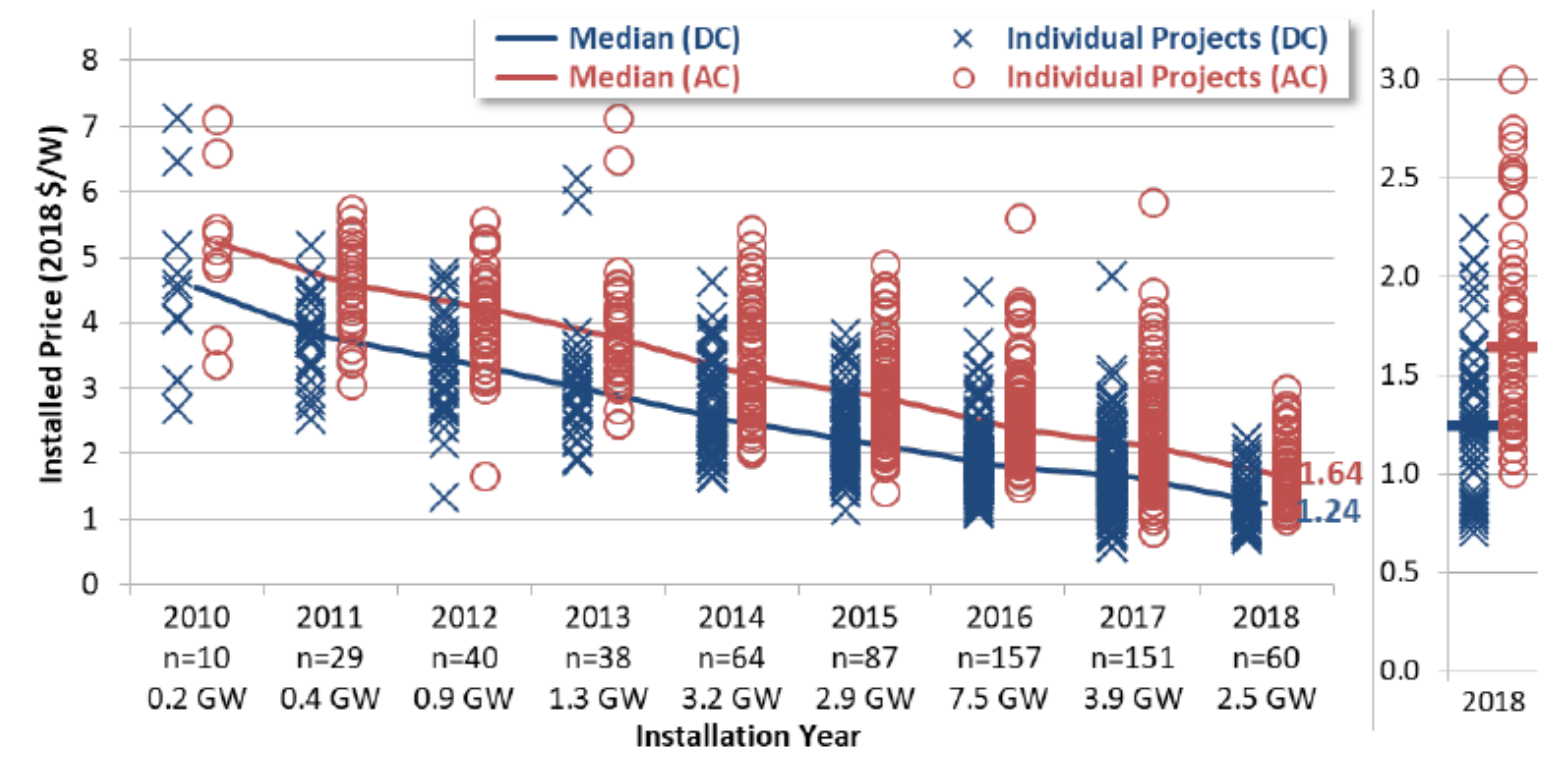

- The median installed price of PV has fallen by nearly $70 \%$ since 2010 , to $\$ 1.6 / \mathrm{WAC}$ (\$1.2/WDC) in 2018.

- The lowest 20th percentile of project prices fell from $\$ 1.7 / \mathrm{WAC}(\$ 1.3 / \mathrm{WDC})$ in 2017 to $\$ 1.3 /$ WAC $(\$ 0.9 / W D C)$ in 2018.

- The lowest projects among the 60 data points in 2018 was $\$ 1.0 /$ WAC $(\$ 0.7 / \mathrm{WDC})$.

- This sample is backward-looking and may not reflect the price of projects built in 2019 and 2020. 


\section{PPA prices have fallen dramatically, in all regions of the country.}

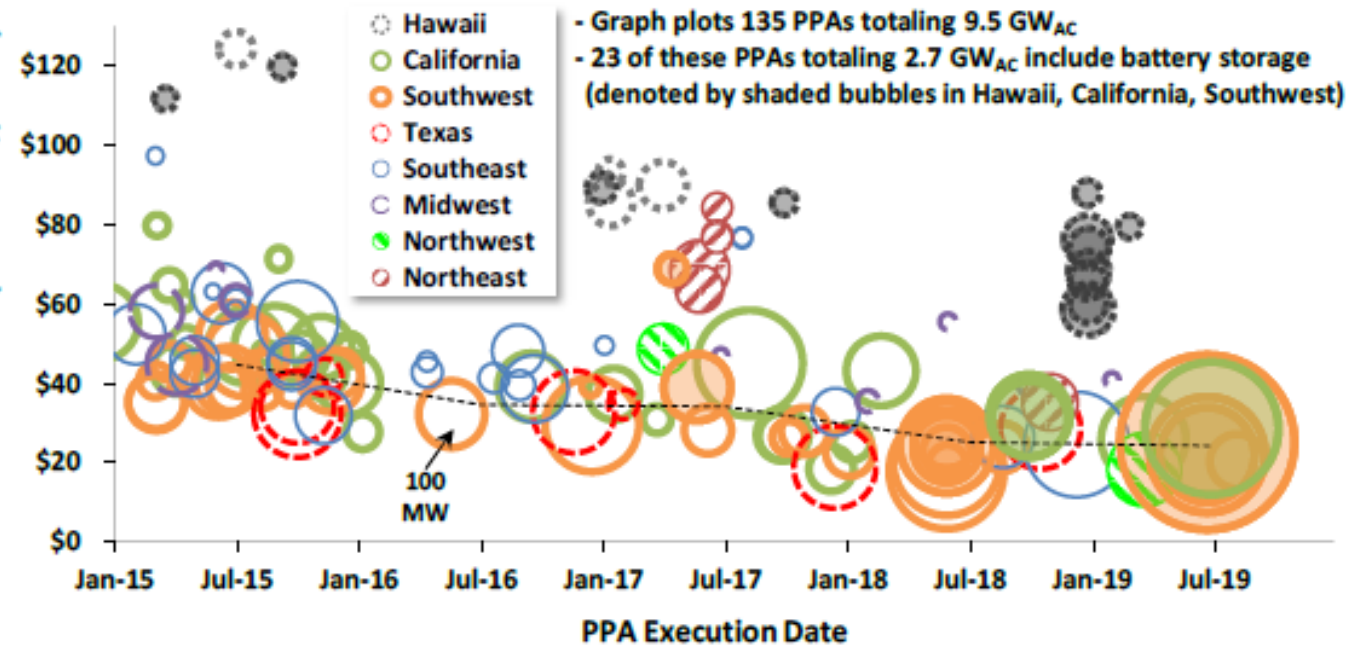

- 27 of 38 post-2017 PPAs in LBNL's sample are $<\$ 40 / \mathrm{MWh}$, with $21<\$ 30 / \mathrm{MWh}$ and 4 even $<\$ 20 / M W h$ (all levelized, in 2018 dollars).

- 23 PPAs featuring PV plus medium-duration battery storage (4-5 hour, shaded in left graph) do not seem to be priced at much of premium to their PV-only counterparts.

- Projects in Hawaii show a consistent and significant premium of $\sim 40 / \mathrm{MWh}$ over the mainland United States.

- Smaller projects (e.g., 20-50 MW) are seemingly no less competitive.

- More than $80 \%$ of the sample is currently operational. 


\section{System Pricing from Select States}

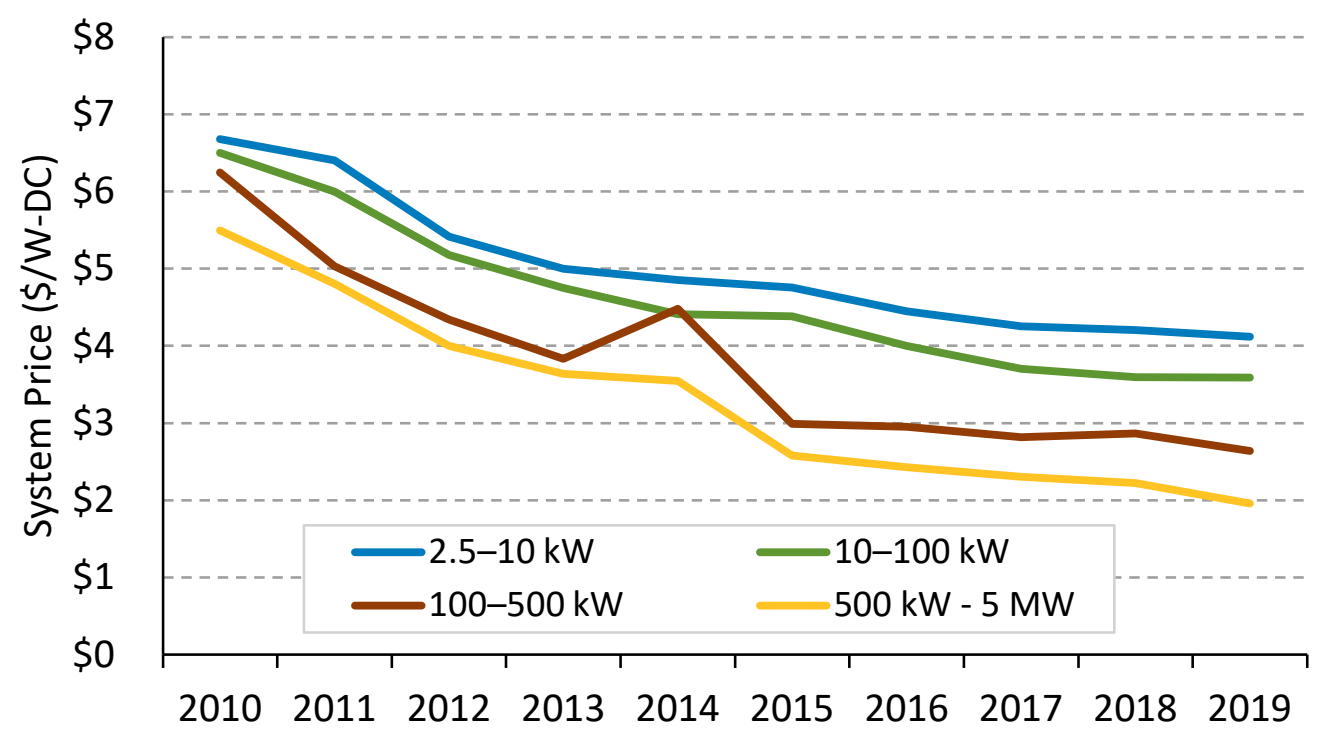

Based on partial data for 2018-2019, the median reported PV system price in California,

Connecticut, Massachusetts, and New York fell:

- $2 \%$ to $\$ 4.12 / \mathrm{W}$ for systems of $2.5 \mathrm{~kW}-10 \mathrm{~kW}$

- $0 \%$ to $\$ 3.59 / \mathrm{W}$ for systems of $10 \mathrm{~kW}-100 \mathrm{~kW}$

- $8 \%$ to $\$ 2.64 / \mathrm{W}$ for systems of $100 \mathrm{~kW}-500 \mathrm{~kW}$

- $12 \%$ to $\$ 1.96 / \mathrm{W}$ for systems of $500 \mathrm{~kW}-5 \mathrm{MW}$. 


\section{System Pricing from Select States, 2019}

- In addition to price differences based on system size, there is also variation between states and within individual markets.

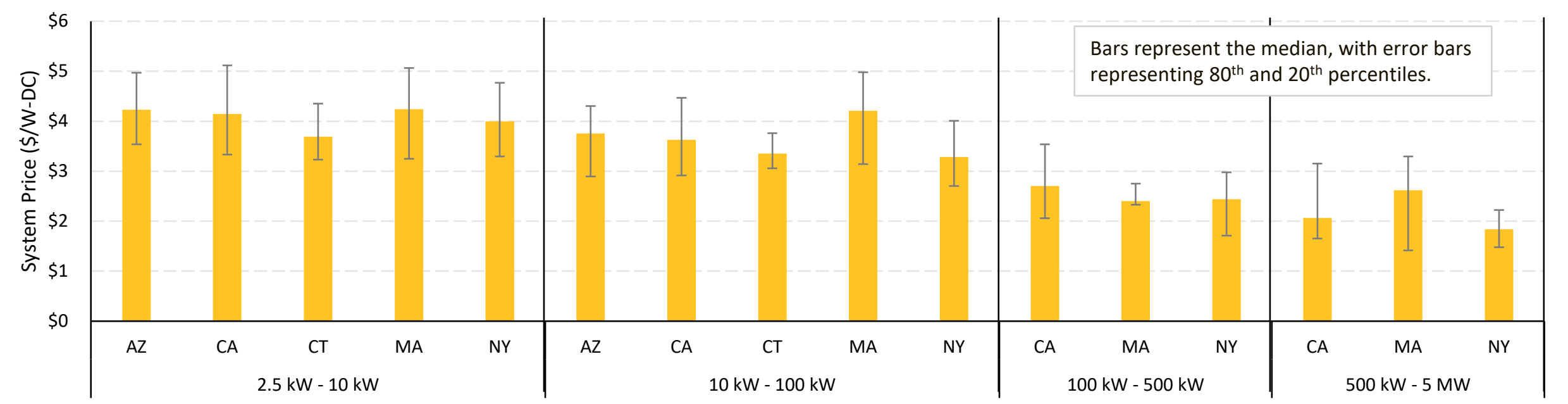




\section{Sunnova, Sunrun, and Vivint Cost and Value}

- For the past three years for Sunnova, Sunrun, and Vivint:

- Total system costs have remained relatively flat or increased.

- Hardware costs have decreased.

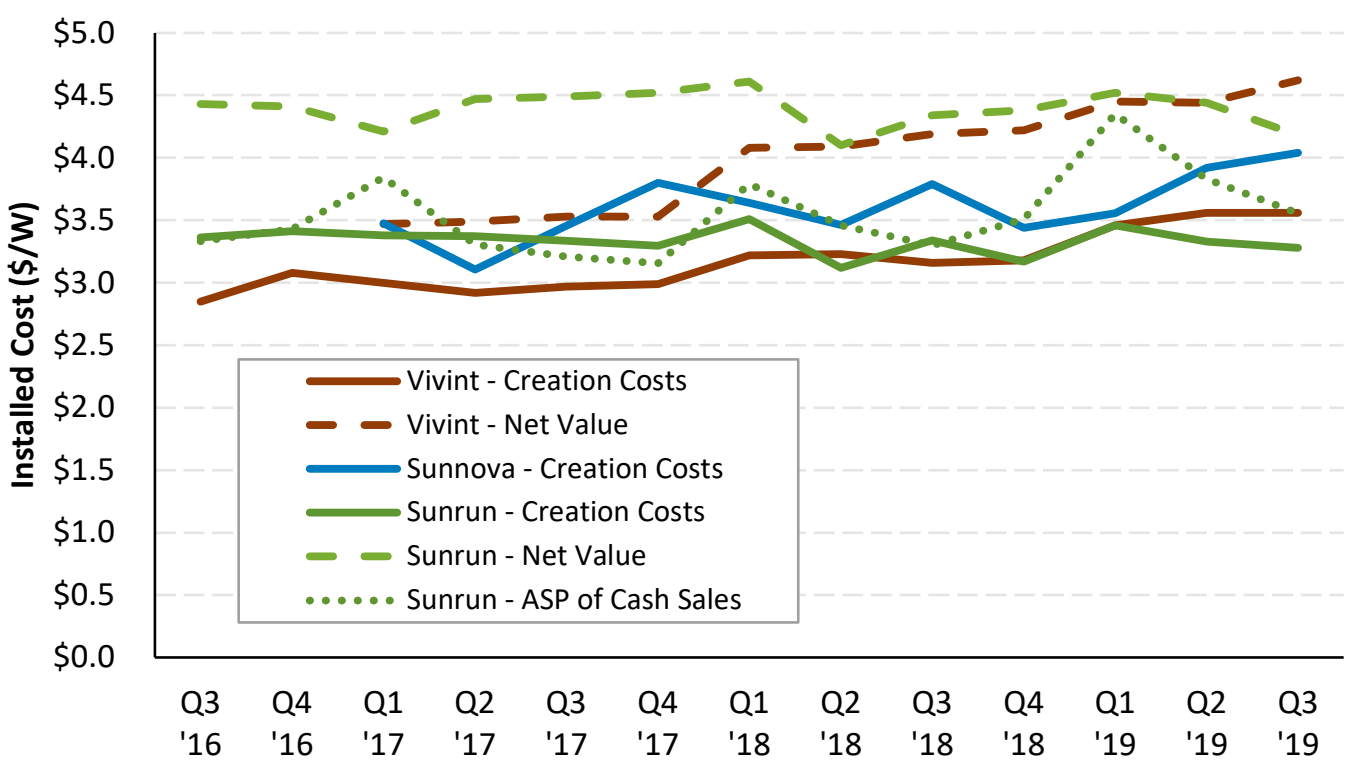

- In Q3 2019, totals costs for Vivint- and Sunrun-built systems were approximately $\$ 3.25 / \mathrm{W}-\$ 3.50 / \mathrm{W}$.

- Sunrun and Vivint still report a PV system net value of $\$ 4.0 / \mathrm{W}-\$ 4.5 / \mathrm{W}$.

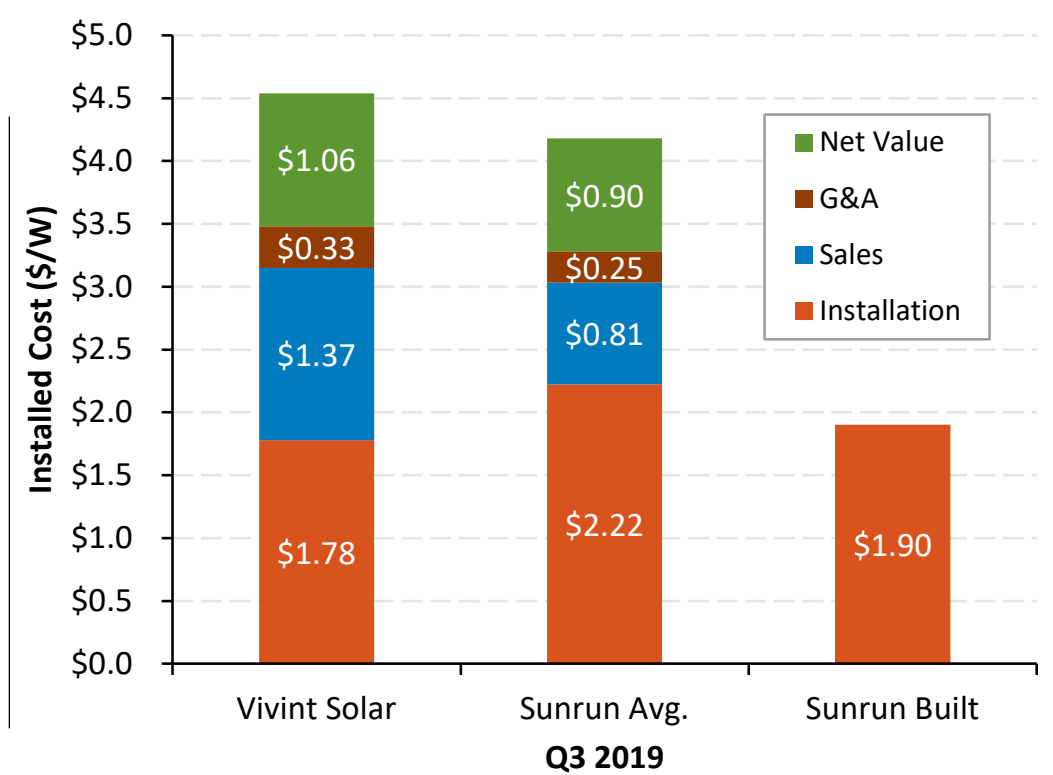




\section{State and Federal Updates}

\section{Global PV Deployment}

\section{U.S. PV Deployment}

\section{PV System Pricing}

\section{Global Manufacturing}

6 Component Pricing

7 Market Activity
- Performance of solar companies rebounded, on average, in Q3 2019 as the ASP of modules stabilized.

- $2.5 \mathrm{GW}$ of PV cells were imported into the United States in 2019, along with $18.6 \mathrm{GW}$ of modules. And the United States manufactured over $600 \mathrm{MW}$ of thin-film modules. 


\section{PV Manufacturers' Margins}

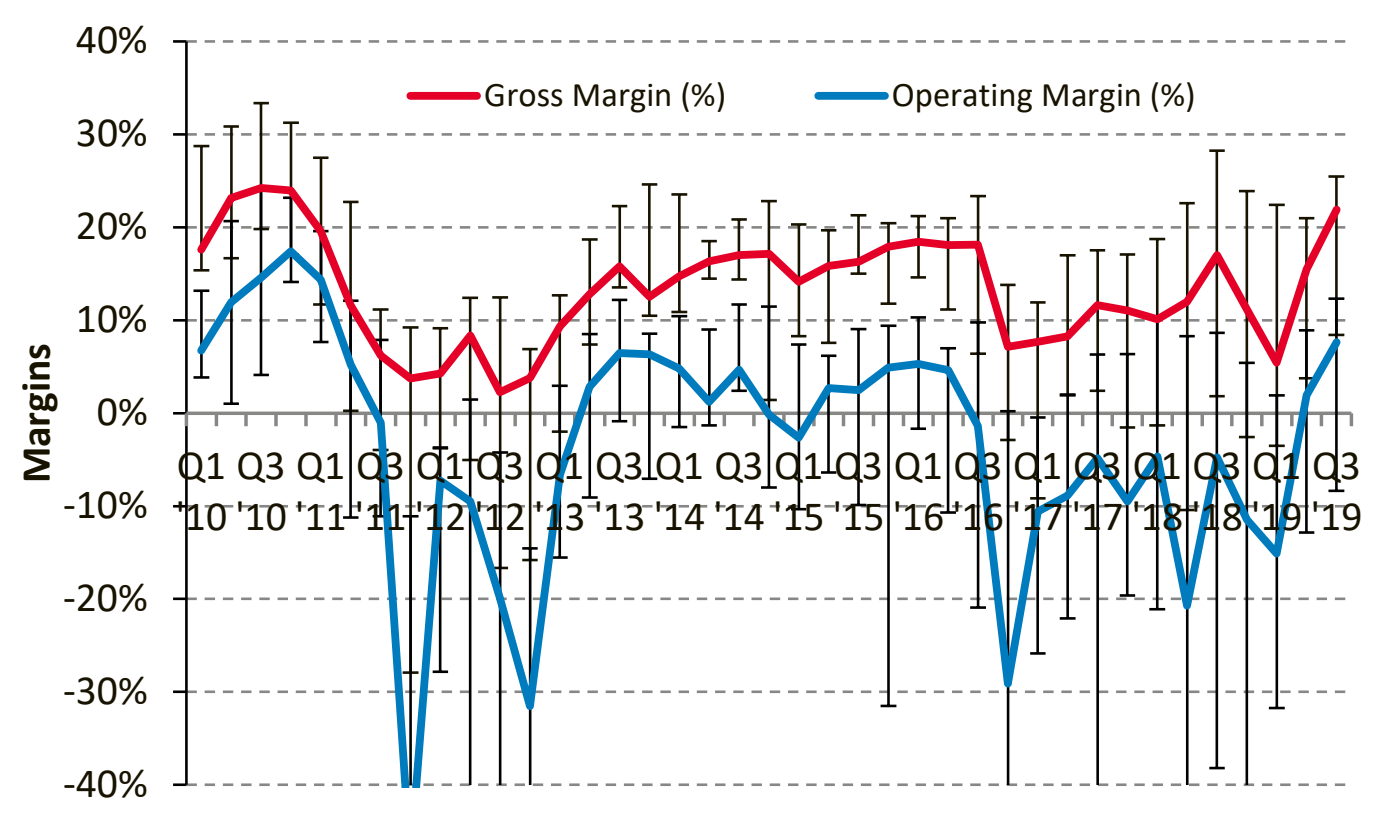

Line represents the median, with error bars representing $80^{\text {th }}$ and $20^{\text {th }}$ percentiles for the following companies in Q3 2019: Canadian Solar, First Solar, HT-SAAE, Jinko Solar, LONGi, Motech Industries, Neo Solar Power, ReneSola, Risen Energy, and SunPower. When they are available, margin data from Hanwha Q Cells, JA Solar, Trina, Yingli, and Hareon Solar are also included for Q1 2010 to Q2 2019.
- Performance of solar companies rebounded, on average, in Q3 2019 as the ASP of modules stabilized and costs declined.

- Average margins for the leading companies have not been this high since 2010-2011.

- First Solar more than doubled its production from Q3 2018 to Q3 2019, as its Series 6 fleet efficiency, throughput, yield, and cost improved.

- LONGi has guided an almost doubling of net profits expected for 2019 , as a results of increased manufacturing scale, lowering production costs and with significant growth in overseas market demand. 


\section{Module and Cell Import Data}

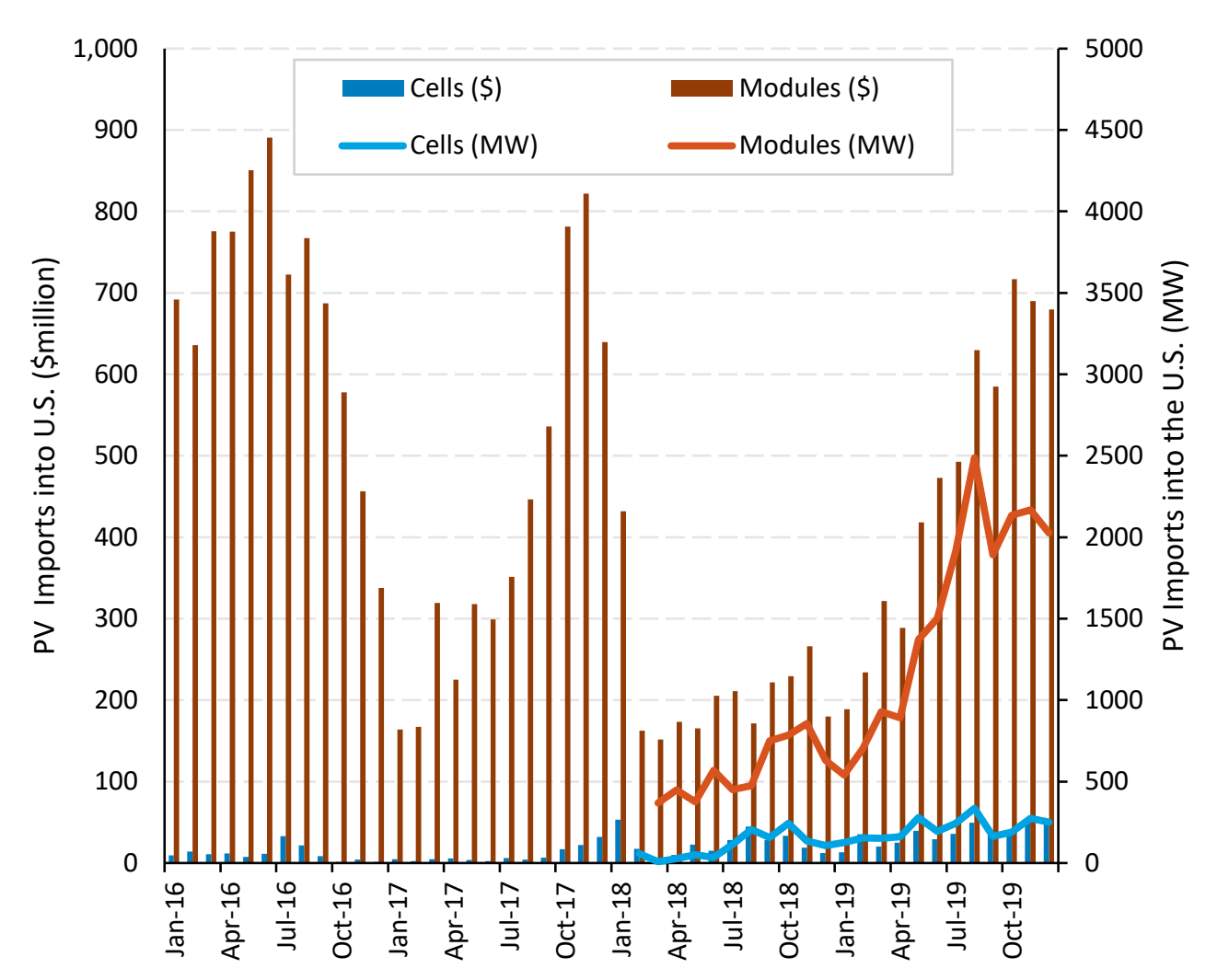

- Despite tariffs, PV modules and cells are being imported at historically high levels.

- 18.6 GW of PV modules were imported in the 2019, with $12.6 \mathrm{GW}$ being imported in the $\mathrm{H} 2$.

- Another 2.5 GW of cells were imported in 2019, with $1.5 \mathrm{GW}$ coming in $\mathrm{H} 2$.

- Total imports of PV cells and modules were 21 GW available to the U.S. market.

- First Solar provides additional module supply to the U.S. market. Its initial production capacity of $0.6 \mathrm{GW}$ is set to ramp to $1.9 \mathrm{GW}$ in 2020 . 


\section{Module and Cell Import Data by Region}

In 2019, Malaysia, Vietnam, Thailand, and South Korea represented nearly $87 \%$ of PV module imports into the United States.

- In total, $96 \%$ of imports came from Asian countries, though a very small percentage came from China.

\section{U.S. Module Imports by Region (18.6 GW)}

Note: cell data uses HTS codes: 8541406030 ,

8541406025; module data uses codes: 8541406015 , 8541406020, 8541406035 Sources: Imports, by value and MW: U.S. International Trade Commission, 2020.
In 2019, South Korea represented almost 50\% of PV cell imports into the United States.

- Korea companies Hanwha and LG announced the opening of $2.2 \mathrm{GW}$ of U.S. module assembly capacity in the first half of 2019.

\section{U.S. Cell Imports by Region (2.5 GW)}

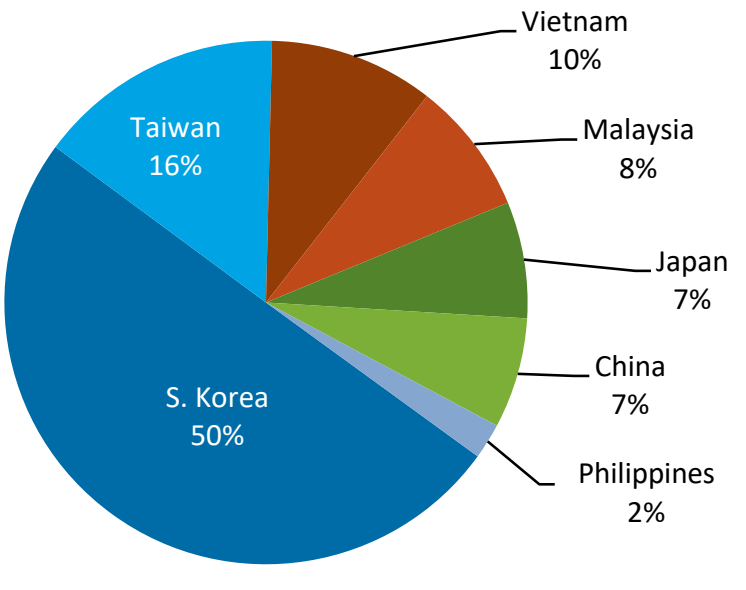




\section{Module Imports by Tariff}

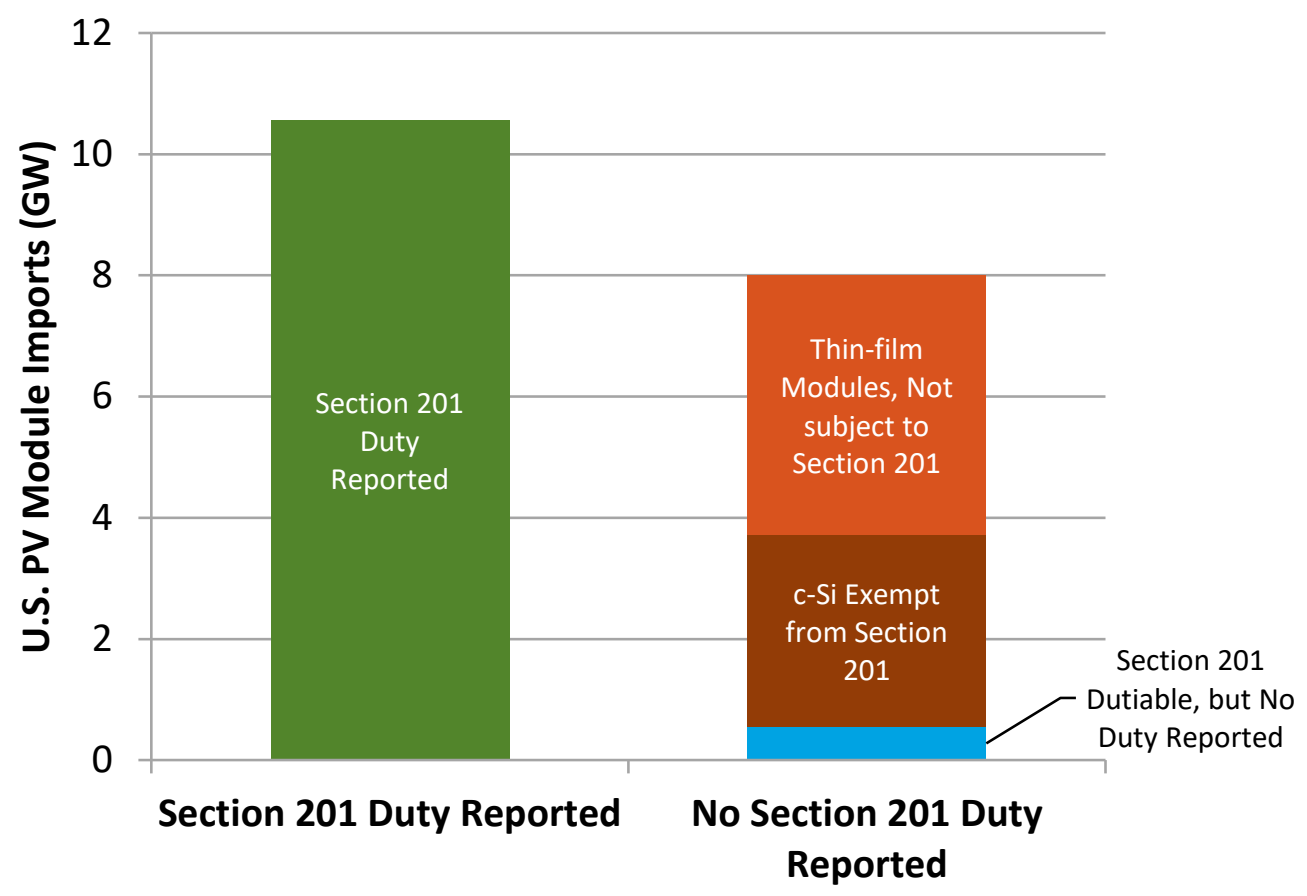

- In 2019, 8 GW of imported PV modules did not report a tariff.

- Most of these modules (4.3 GW) were thin-film; however, another $3.2 \mathrm{GW}$-mostly from South Korea, Vietnam, Thailand, Malaysia, and Mexico-reported their modules as c-Si and exempt from the Section 201 duties.

- The imports from Mexico are likely SunPower IBC panels, which received an exemption.

- Another portion may be bifacial modules, which were exempt from Section 201 duties from June through October of 2019.

- Approximately $0.6 \mathrm{GW}$ of c-Si modules, subject to Section 201, were imported; however, no duties were reported. Why this happened is unclear.

Note: module data uses codes: $8541406015,8541406020,8541406035$. We assume all modules not subject to Section 201 tariffs are reported under "Free under HS Chapters 1-98" or "Entered into U.S. Virgin Islands," with exemptions coming from HTS code 8541406015, and technologies not applicable reported under HTS code 854140603 . We assume all panels subject to Section 201 duties have been reported under, "Dutiable- HS chapter $99 . "$ 


\section{Cell Import Data by Tariff}

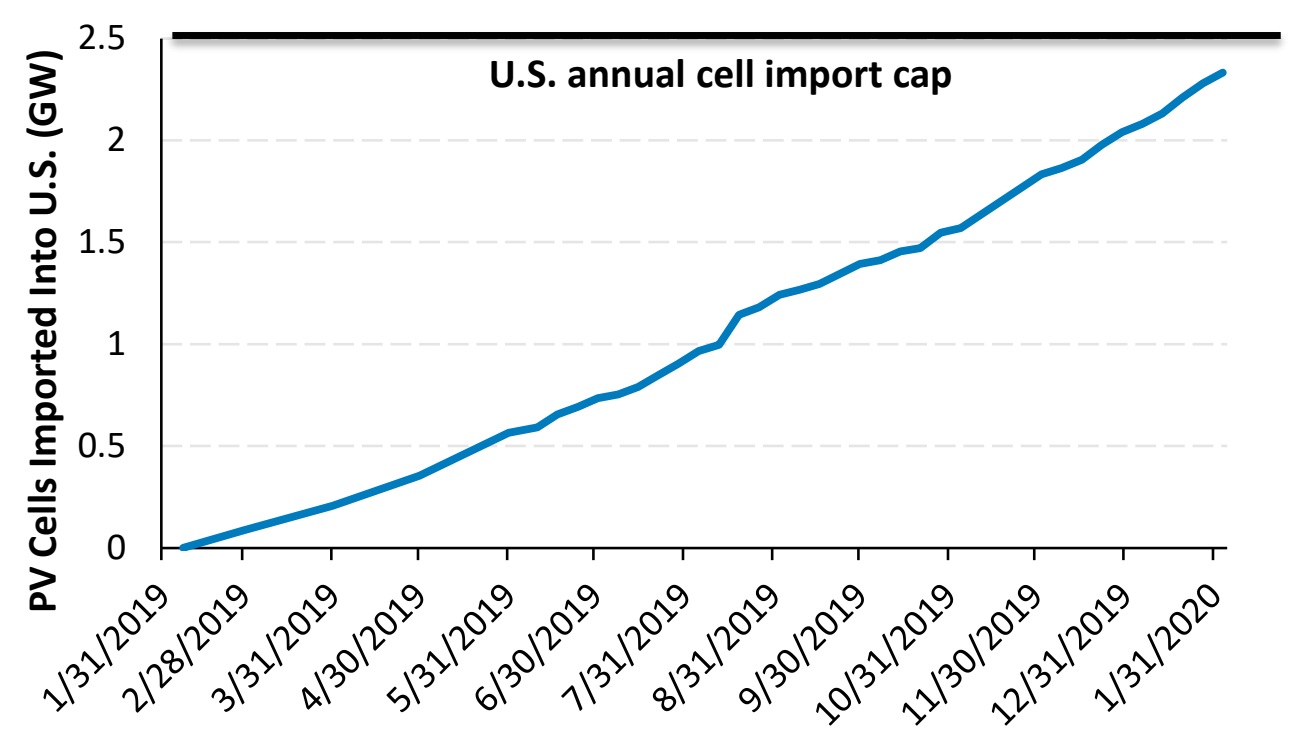

A 2.5-GW quota (February 7, 2019- February 6, 2020) exempts the first $2.5 \mathrm{GW}$ of imported c-Si PV cells, subject to the Section 201 tariff.

- Over that period, the United States imported approximately $2.3 \mathrm{GW}$, which is $200 \mathrm{MW}$ short of the cap.

- From December 2019 to February 2020, monthly imports increased to an average of $250 \mathrm{MW}$.

- If PV cell imports stay at current import levels, they will exceed the cap in 2020-2021.

- While the United States imported more than $2.5 \mathrm{GW}$ in the 2019 calendar year, some cells, like modules, were exempt from the quota.

- IBC cells, bifacial cells, and cells from some developing countries.

- Cell imports in January 2019 (126 MW) were much lower than those in January 2020 ( $290 \mathrm{MW}$ ). 


\section{BNEF: 2019 PV Manufacturing Capacity Review}

- BNEF reports significant overcapacity across the PV supply chain, driving $21 \%$ of manufacturers out of business in 2019.

- BENF expects more capacity expansion and company exits in 2020.

GW/year

265

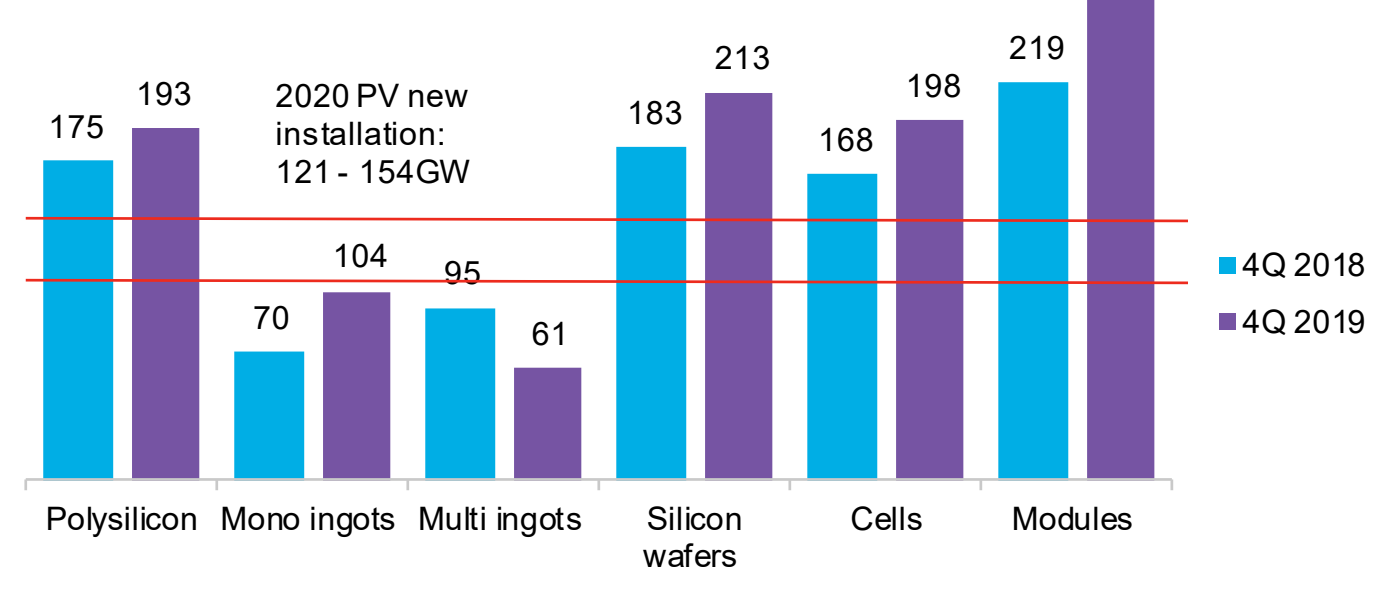

Source: BNEF “2019 PV manufacturing Capacity Review.” January 2020.
- Large levels of capacity expansion, by industry leaders, forced older factories and other firms out of the market, with overall capacity increasing.

- BNEF reports than tens of gigawatts of manufacturing capacity closed in 2019 across the value chain.

- Manufacturers have started to incorporate halfcut, glass-glass, multi-busbar, and shinglestructure modules into their production lines.

- Since 2015, manufacturers have supplied a greater and greater share of mono c-Si PV, which represented over half the market in 2019. BNEF expects this share to increase to three-quarters by 2021 . 


\section{State and Federal Updates}

\section{Global PV Deployment}

\section{U.S. PV Deployment}

\section{PV System Pricing}

\section{Global Manufacturing}

6 Component Pricing

7 Market Activity
- In Q3 2019, PV module and component prices again fell to historical lows, with multi- and mono c-Si module ASP falling to $\$ 0.20 / \mathrm{W}$ and $\$ 0.22 / \mathrm{W}$ in September respectively.

- Polysilicon prices also fell to historical lows, pushing some manufacturers out of the market.

- U.S. multi- and mono c-Si module ASP were $41 \%$ and $69 \%$ higher than the global average.

- From 2018 to 2019, lithium-ion battery prices dropped $13 \%$. 


\section{PV Value Chain Spot Pricing}

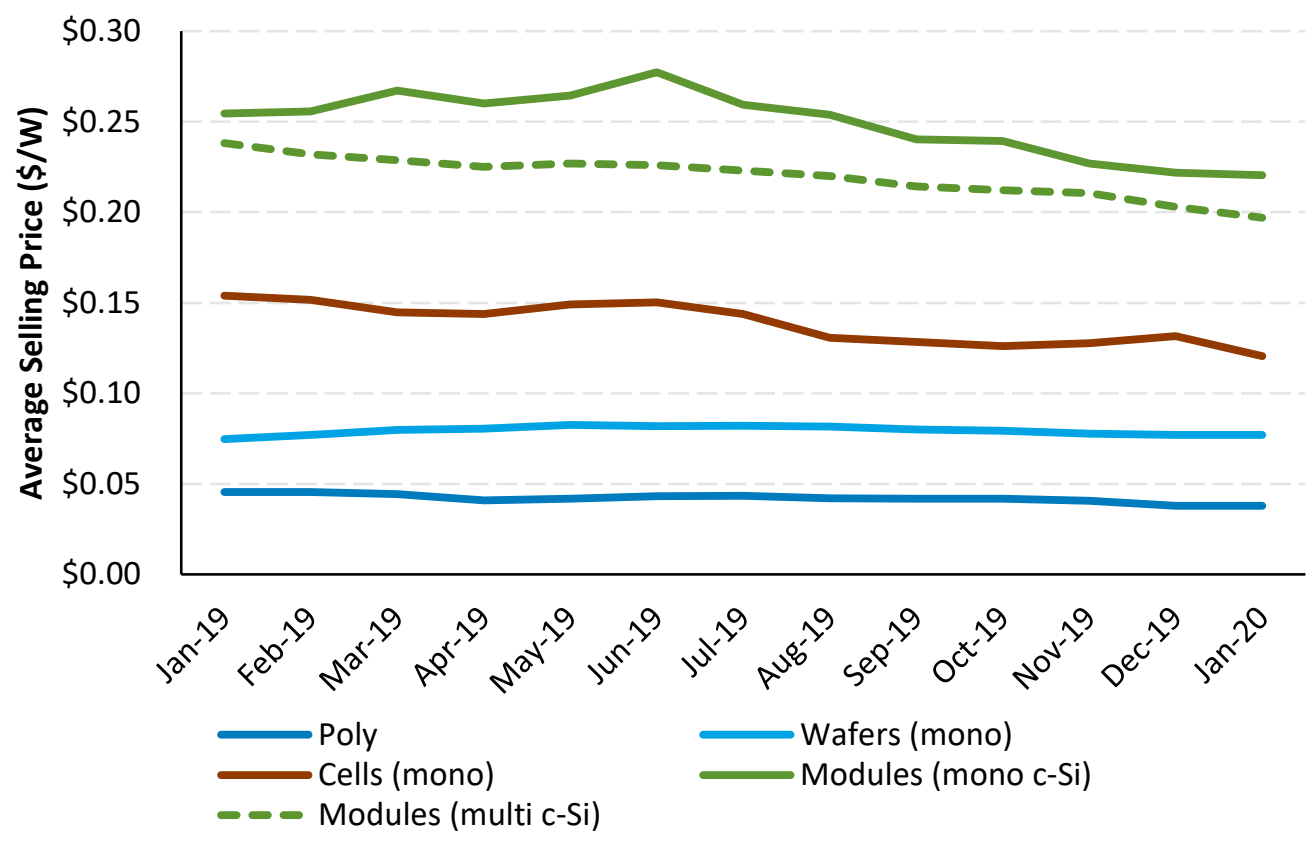

In Q4 2019, PV module and component prices again fell to historical lows, with multi- and mono c-Si module ASP falling to $\$ 0.20 / \mathrm{W}$ and $\$ 0.22 / \mathrm{W}$ in December respectively.

- Polysilicon ASP recorded a low of $\$ 7.1 / \mathrm{kg}$ in December as well.

- The Korean manufacturer $\mathrm{OCl}$ announced in Q1 2020 it was closing two solar grade polysilicon plants because of low prices; another Korean manufacturer, Hanwha, announced in February 2020 it will exit the polysilicon business by the beginning of next year. 


\section{Module Average Selling Price:}

Global versus United States

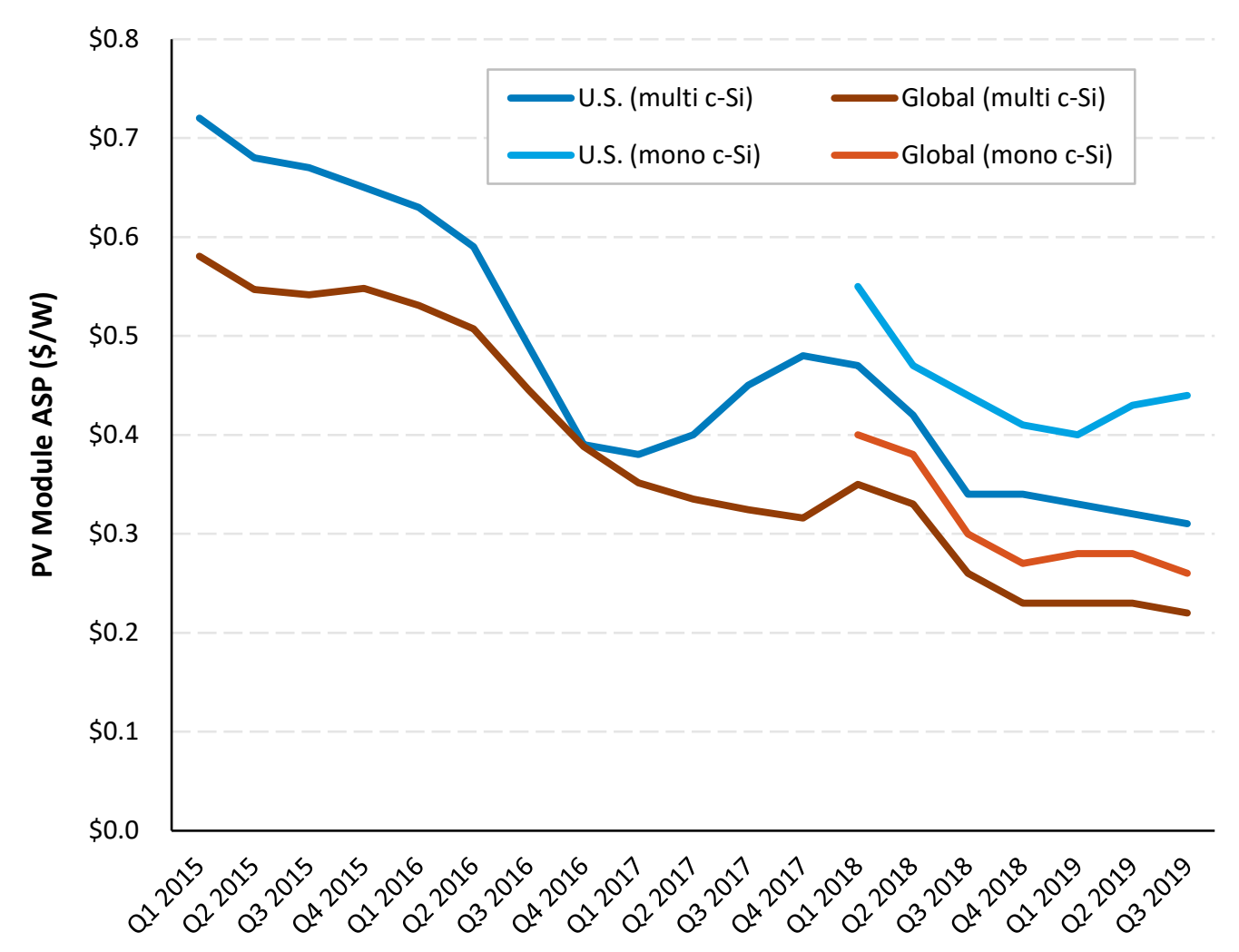

- Global and U.S. module pricing in Q3 2019 continued to fall, except for U.S. mono c-Si modules where strong demand has increased ASP $10 \%$ since the beginning of the year.

- Wood Mackenzie also began tracking U.S. bifacial mono PERC module pricing, which was approximately $15 \%$ below monofacial mono PERC in Q3 2019, owing to its exemption from the Section 201 tariffs.

- Multi- and mono c-Si modules sold in the United States in Q3 2019 were 9\% and 0\% lower in price than modules sold in the United States in Q3 2018, respectively, but they were $41 \%$ and $69 \%$ higher in price than the global average. 


\section{Inverter Pricing}

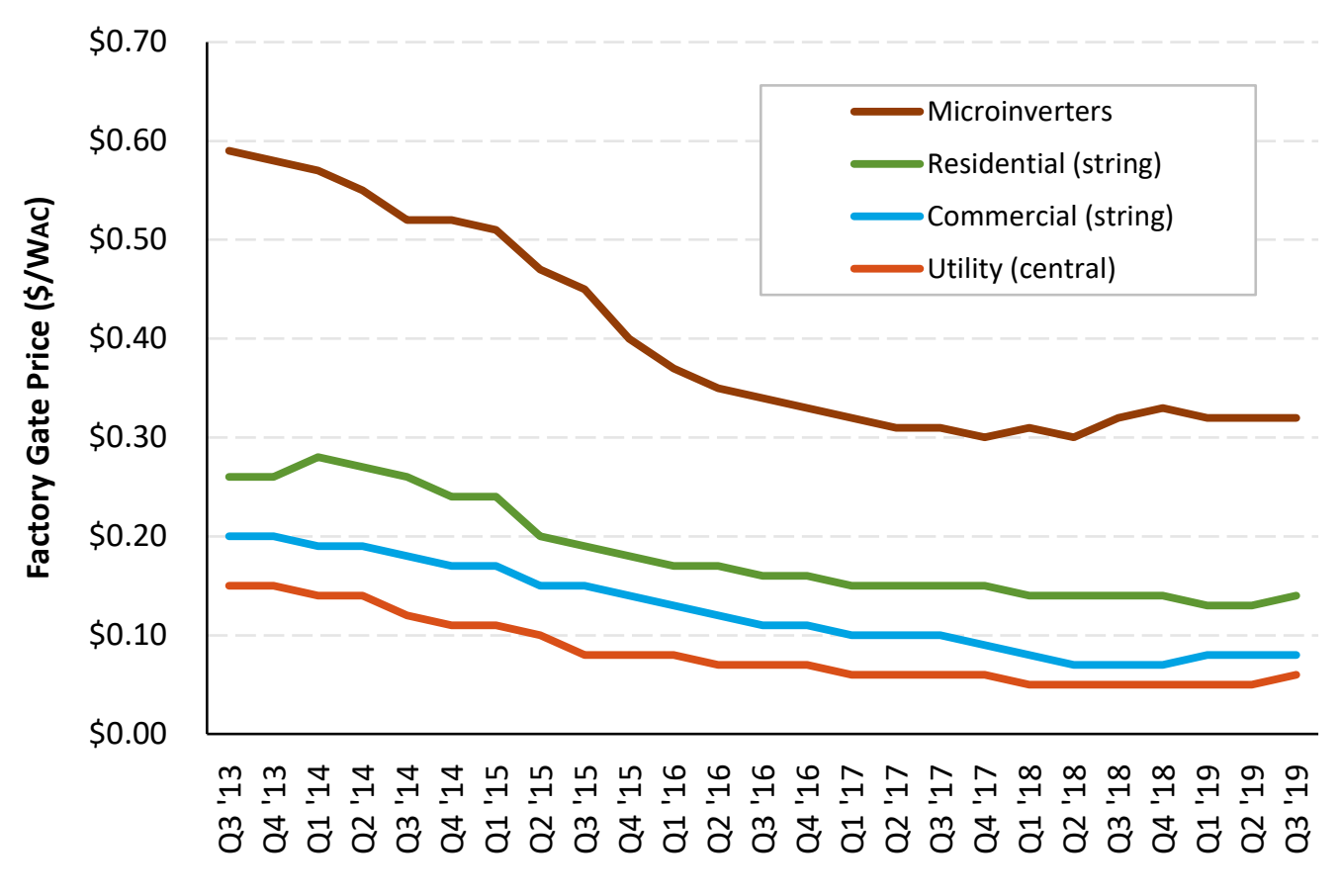

Inverter pricing in the United States has been flat or increased in 2019.

- U.S. tariffs on Chinese inverters has affected suppliers with a large footprint in China, though some companies are trying to diversify their supply chains.

- The rush to start construction on U.S. projects to qualify for the $30 \%$ ITC also created an increase in demand for PV equipment, lifting prices upwards. 


\section{Average Lithium-ion Battery Pack Price, 2010-2019}

Battery pack price (real $2019 \$ / \mathrm{kWh}$ )

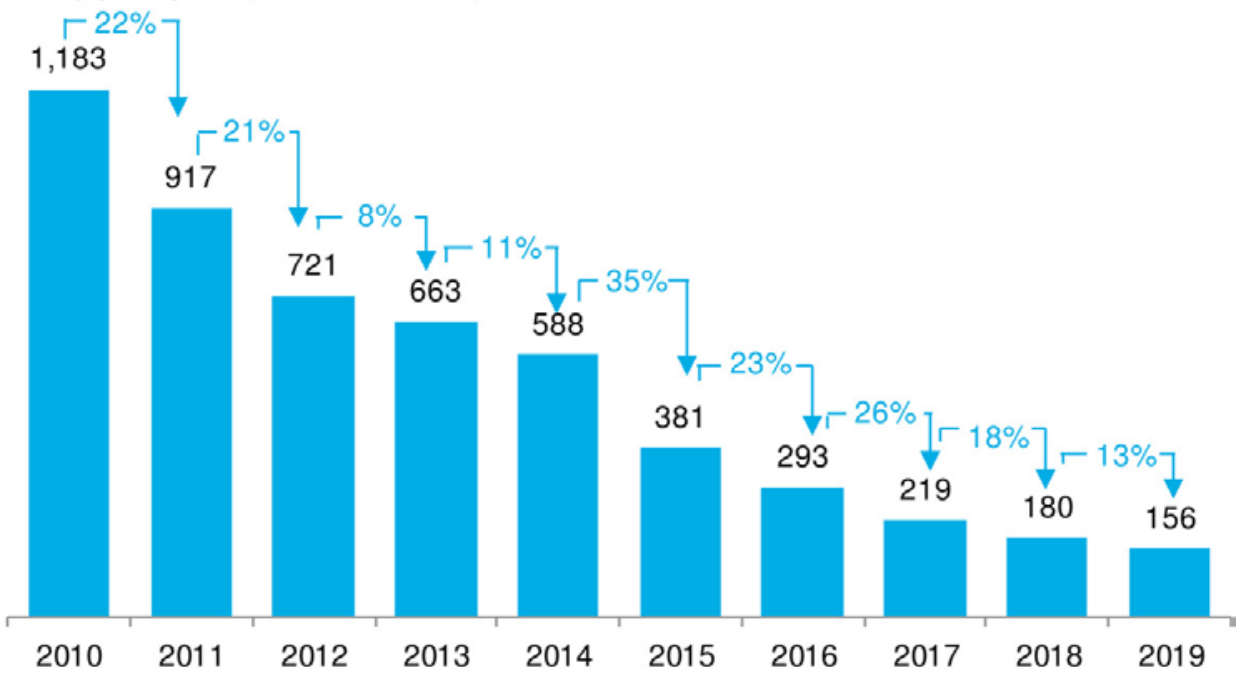

- From 2010 to 2019 , average battery pack prices dropped $87 \%$.

- From 2018 to 2019 alone, prices dropped $13 \%$.

- The survey includes 100 data points across electric vehicles and stationary storage.

- BNEF said that cost decreases can be attributed to increased sales volume, the adoption of new cell designs, and the introduction of higher energy-density cathodes.

- The introduction of new pack designs and falling manufacturing CAPEX is expected to continue price reductions.

- BNEF expects average battery price to fall to $\$ 93 / \mathrm{kWh}$ by 2024 and $\$ 61 / \mathrm{kWh}$ by 2030. 


\section{State and Federal Updates}

\section{Global PV Deployment}

\section{U.S. PV Deployment}

\section{PV System Pricing}

\section{Global Manufacturing}

6 Component Pricing

7 Market Activity
- From January 2, 2015 to January 2, 2020 solar stocks, on average, did not appreciate, though they gained $70 \%$ in 2019 and another $18 \%$ in the first two weeks of February 2020.

- In 2019, solar investment totaled approximately $\$ 139$ billion, with $91 \%$ going to solar projects.

- U.S. solar investment totaled \$25 billion in 2019.

- As of February 2020, there nearly 250,000 solar jobs in the United States-down 4\% from the 2016 peak but up $2 \%$ y/y. 


\section{SREC Pricing}

- Maryland's SREC prices hit a three-year high due to an increase in the RPS implemented in 2019.

- The bill was enacted without the signature of the governor, who plans to propose his own bill next year.

- Proposed increases to solar mandates in Pennsylvania, as well as the closure of out-of-state systems, has increased PA SRECs over the past 18 months.

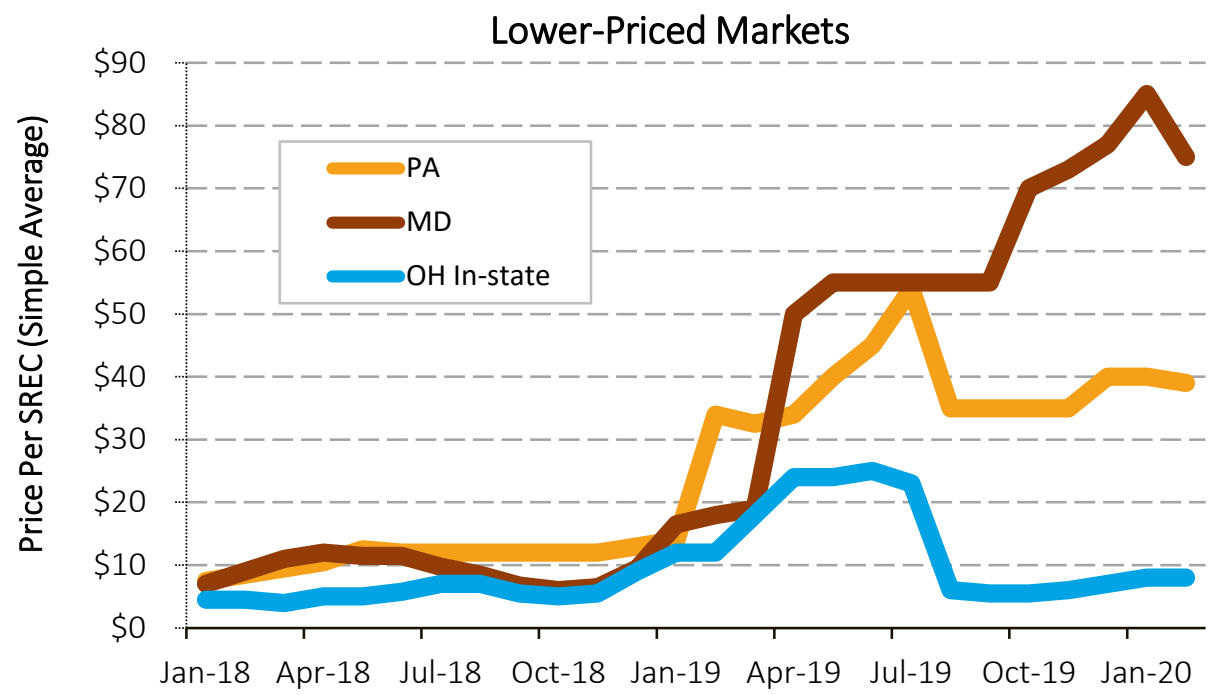

Sources: SRECTrade, https://www.srectrade.com/, accessed 02/14/20.
- After Ohio decreased the overall RPS and eliminated the solar carveout completely in July, SREC prices sharply declined but stabilized throughout the following months.

- In December 2019, New Jersey finalized a transitional incentive program from its current market SREC program, with the following proposed fixed-pricing scenario: $\$ 65 / \mathrm{MWh}$ for 3 years, followed by $\$ 189 / \mathrm{MWh}$ for 12 years. Residential and most ground-mounted systems would earn 0.6 of the credit-spot SREC pricing remained unchanged.

- The New Jersey SREC transition takes effect when 5.1\% of electricity sold in the state comes from solar, which is projected to happen by mid- 2020 .

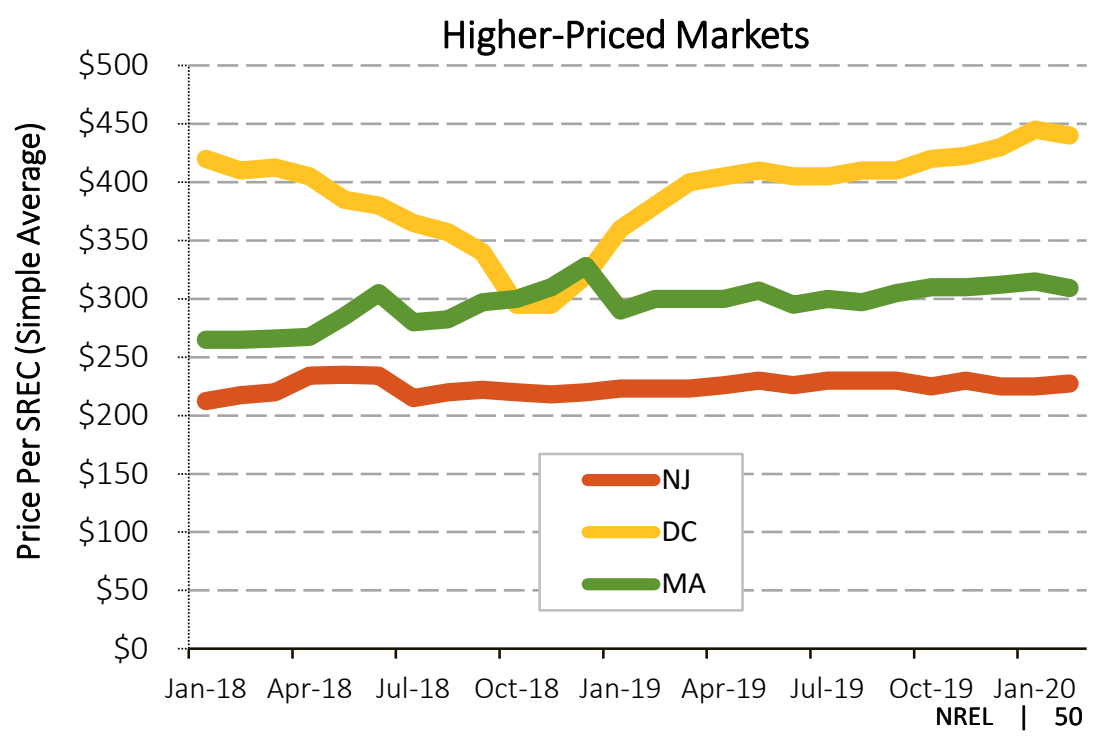




\section{Stock Market Activity}

- Over the past five years, solar stocks have had large fluctuations in the market relative to the broader stock market.

- From January 2, 2015 to January 2, 2020, the Invesco Solar ETF did not appreciate, but it gained $70 \%$ in 2019 and another $18 \%$ in the first two weeks of February 2020.

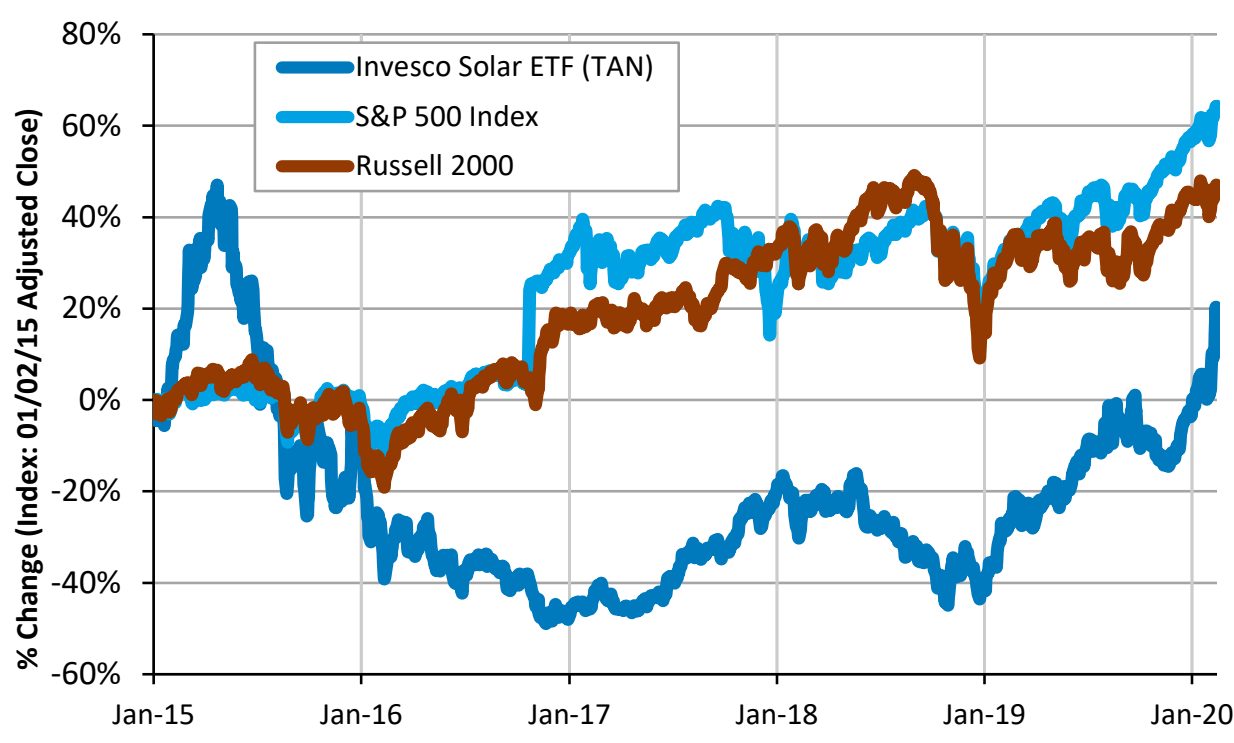

Sources: Stock market: Yahoo Finance (02/14/2020); individual stocks: Mercom (01/06/20).
- Not all solar submarkets or stocks performed the same in the 2019.

- Two inverter manufacturers, Enphase and SolarEdge, were the best performing solar-related stocks, well over doubling in value.

- Recently updated rapid shutdown rules in many states have increased demand for module-level power electronics.

- Equipment manufacturer Meyer Burger, polysilicon manufacturer Wacker Chemie, and solar cell manufacturer Shunfeng all lost value in 2019.
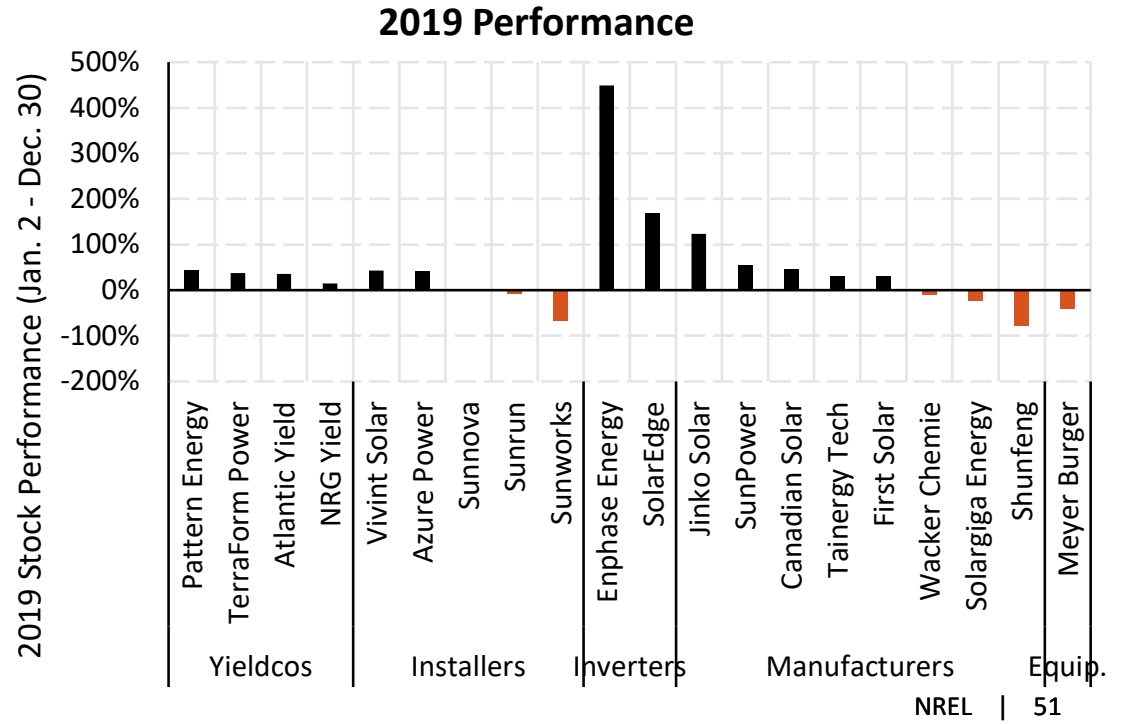


\section{Global Solar Investments}

- In 2019, non-project global solar public market investments grew $10 \% \mathrm{y} / \mathrm{y}$, continuing the rebound from the 2016 contraction.

- Combined, capital raises in the public markets and through VC\&PE grew by around $\$ 1$ billion in 2019, y/y.

- The largest solar deals in 2019 were a $\$ 466$ million IPO of the Chinese PV, which spun off from its parent company (a solar glass manufacturer) and a $\$ 866$ million VC\&PE capital raise for Greenko (an Indian project development company).

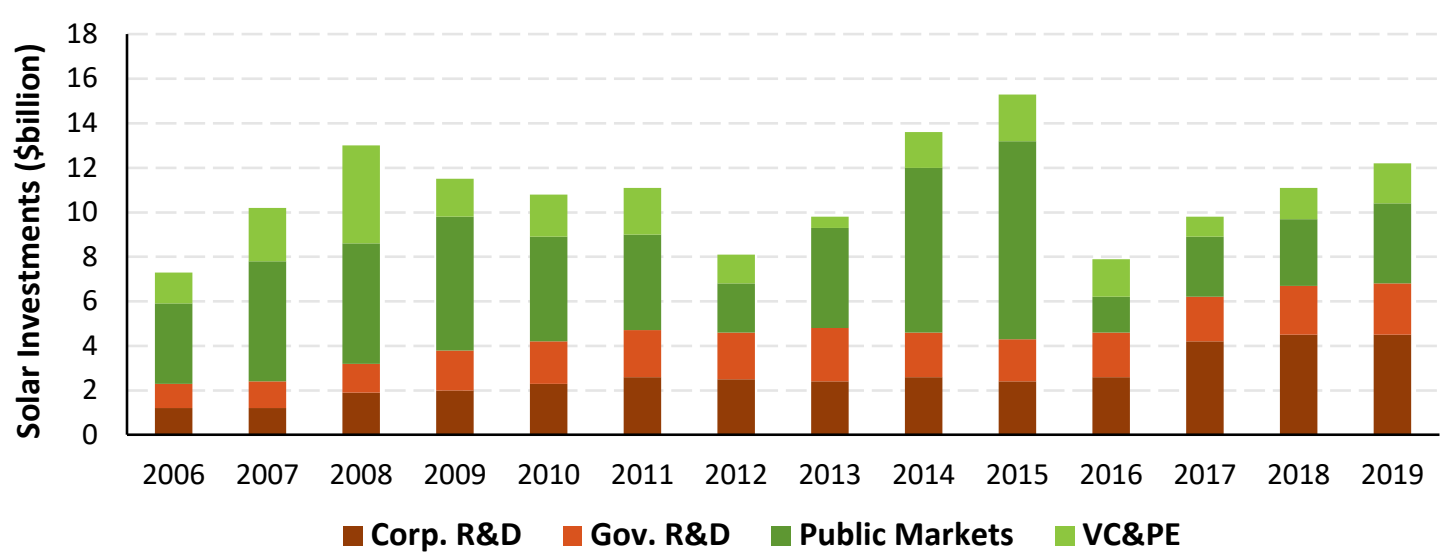

Source. BNEF, "Clean Energy Investment Trends 2019."
- Since 2011, global investments in solar energy have been approximately $\$ 150$ billion per year.

- Most of the global investment in solar has historically gone to funding of projects-91\% in 2019.

- While government R\&D funding was relatively consistent the past decade, corporate R\&D funding grew approximately $75 \%$ from 2016 to 2019 .

- Public markets and VC\&PE have varied significantly more over time, with a significant increase in public markets in 2013-2015 going toward yieldcos (e.g., Terraform and 8point3) and thirdparty residential companies (e.g., SolarCity and SunPower)both of which were lower since 2016.

\section{Global Solar Investments (\$139 billion)}

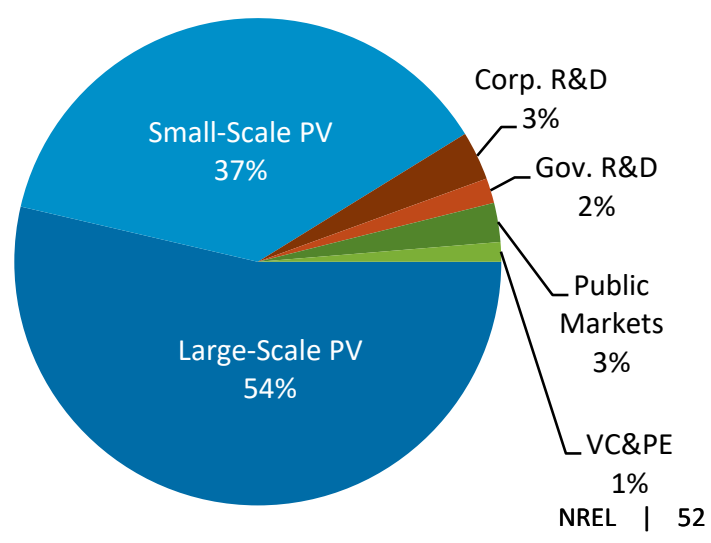




\section{U.S. Solar Investments}

- U.S. public markets in 2013-2015 raised funds for yieldcos (e.g., Terraform and 8point3) and third-party residential companies (e.g., SolarCity, SunPower) - but they dropped precipitously in 2016.

- The largest U.S. solar deals in 2019 were a \$250 million public offering from Terraform (a renewable energy asset owner) and a $\$ 200$ million VC\&PE capital raise for Madison Energy Investments (a developer/owner/operator of U.S. distributed PV assets).

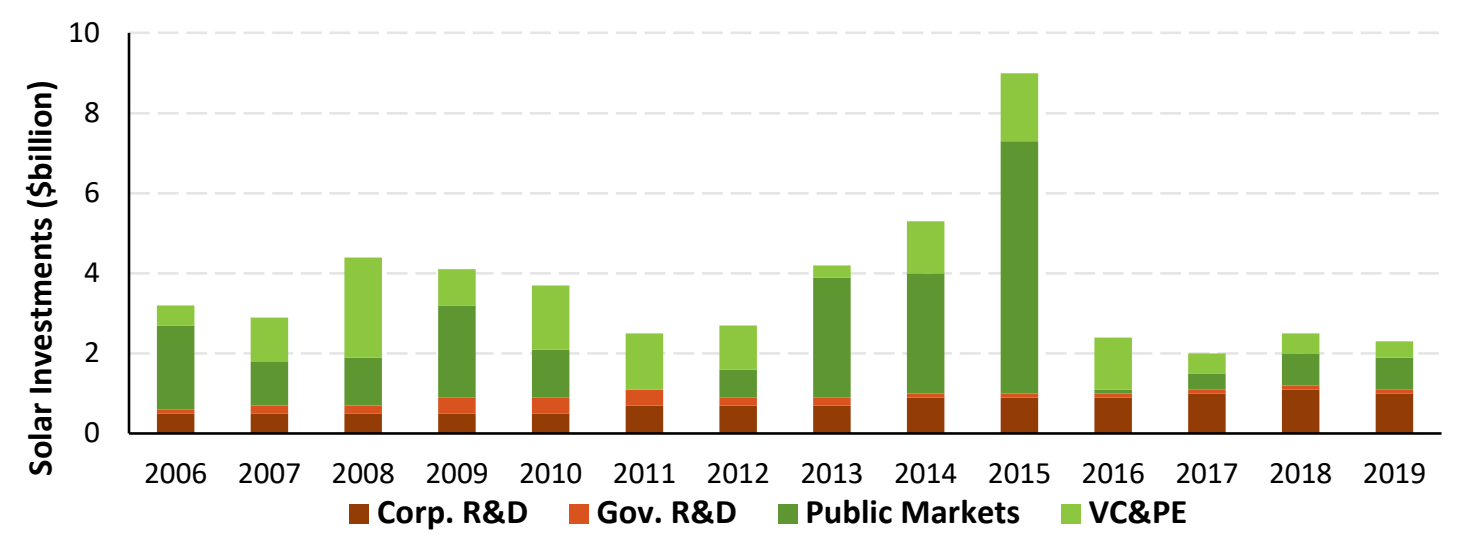

- Total U.S investments in solar energy grew by about $12 \%, y / y$, to $\$ 25$ billion due to significant growth in project funding.

- Most U.S. investment in solar has historically gone to funding projects-91\% in 2019.

\section{U.S. Solar Investments} (\$25 billion)

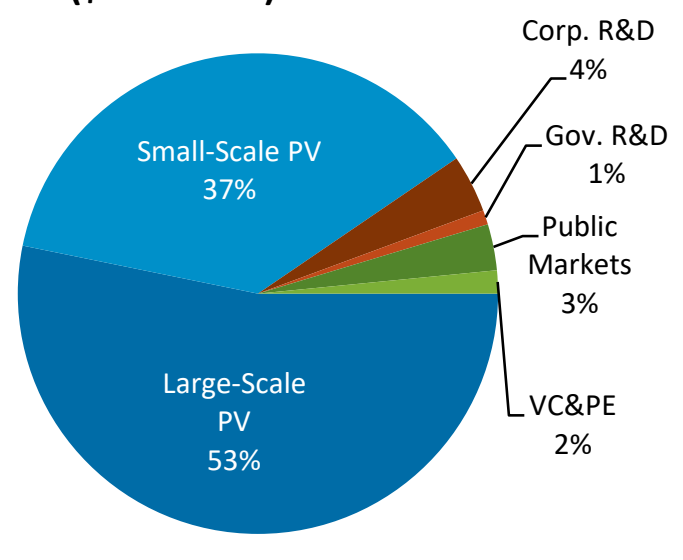




\section{U.S. Solar Workforce}

- As of February 2020, there nearly 250,000 solar jobs in the United Statesdown $4 \%$ from the 2016 peak but up $2 \%$ y/y.

- The Solar Foundation attributes this growth to an increase in PV installations from 2018 to 2019.

- Respondents of the job survey predicted that solar jobs will increase to nearly 270,000 by the end of 2020 .

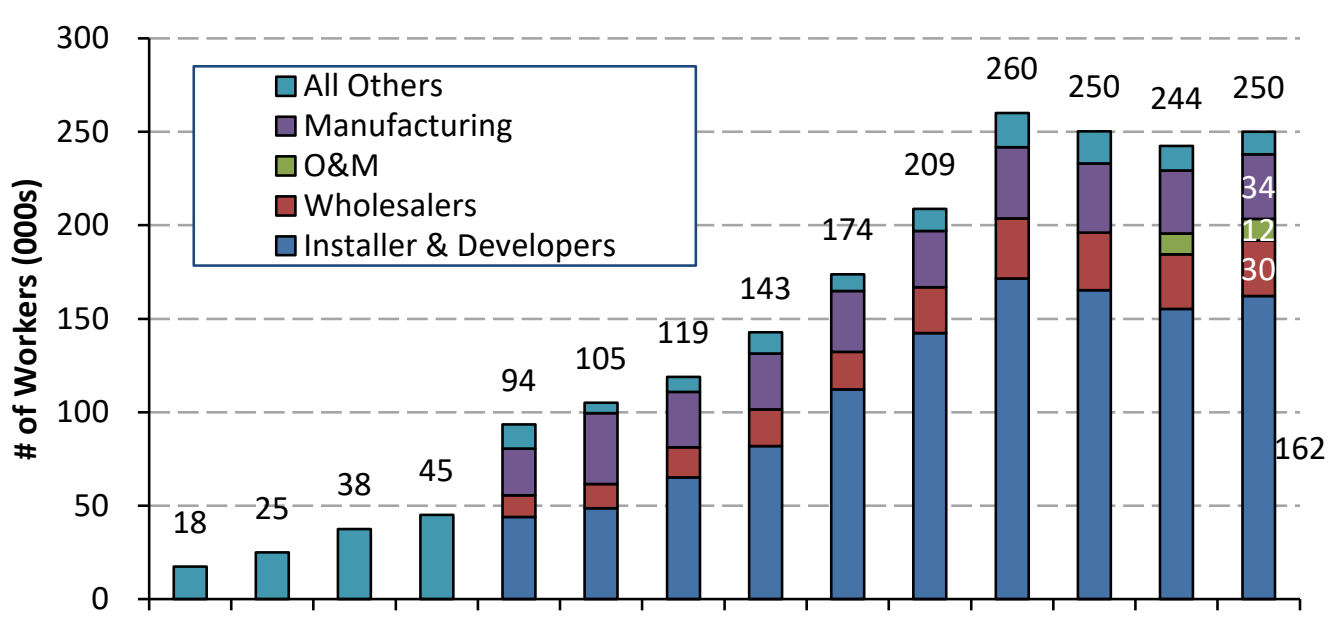

20062007200820092010201120122013201420152016201720182019

Source. The Solar Foundation, “The National Solar Jobs Census 2019.” February 2020.
- While solar employment decreased in some markets, such as CA, TN, MI, MN, and WA; solar jobs increased in 31 states, such as FL, GA, UT, NY, and TX.

- Job growth and losses often correlated with annual deployment-however, not always (potentially owing to uneven job intensiveness per sector).

- Among the 162,000 solar installation jobs, $56 \%$ focus on the residential market, $25 \%$ on non-residential, and $19 \%$ on utility-scale PV.

- Solar wages remain above national averages, with non-electrician mid-level employees receiving approximately $\$ 23 /$ hour, and electricians receiving $\$ 28 /$ hour.

- In 2019, women represented approximately $26 \%$ of the solar workforce, non-white employees represented $27 \%$, and veterans $8 \%$, compared to $47 \%, 20 \%$, and $6 \%$ of the overall U.S. workforce, respectively. 
Special thanks to Dan Bilello, Jeff Logan,

and Mike Meshek.

\section{Thank You}

www.nrel.gov

NREL/PR-6A20-76158

This work was authored by the National Renewable Energy Laboratory, operated by Alliance for Sustainable Energy, LLC, for the U.S. Department of Energy (DOE) under Contract No. DE-AC36-08GO28308. Funding provided by the U.S. Department of Energy Office of Energy Efficiency and Renewable Energy Solar Energy Technologies Office. The views expressed in the article do not necessarily represent the views of the DOE or the U.S. Government. The U.S. Government retains and the publisher, by accepting the article for publication, acknowledges that the U.S. Government retains a nonexclusive, paid-up, irrevocable, worldwide license to publish or reproduce the published form of this work, or allow others to do so, for U.S. Government purposes. 


\section{List of Acronyms and Abbreviations}

- $\mathrm{AC}$

- aEO

- APR

- ASP

- BNEF

- $\mathrm{C}$

- $\quad \mathrm{C}-\mathrm{Si}$

- CSP

- $\mathrm{DC}$

- DPV

- eIA

- eRCOT

- ETF

- FERC

- GW

- GWh

- IBC

- IPO

- ILR

- ITC

- $\mathrm{kg}$

- $\mathrm{kW}$

- kWh

- MOPR alternating current

annual energy outlook

annual percentage rate

average selling price

Bloomberg New Energy Finance

Celsius

crystalline silicon

concentrating solar power

direct current

distributed photovoltaic

U.S. Energy Information Administration

Energy Reliability Council of Texas

exchange-traded fund

Federal Energy Regulatory Commission

gigawatt

gigawatt-hour

interdigitated back contact

initial public offering

inverter loading ratio

investment tax credit

kilogram

kilowatt

kilowatt-hour

minimum offer price rule
- MW

- $\mathrm{MWh}$

- NEM

- PERC

- PPA

- PNM

- PV

- R\&D

- $\mathrm{RE}$

- $\mathrm{Q}$

- $\mathrm{Q} / \mathrm{Q}$

- RE

- ROW

- RPS

- S\&P

- SEIA

- Seto

- SREC

- TPO

- UPV

- VC\&PE

- $\mathrm{W}$

- $y / y$ megawatt

megawatt-hour

net energy metering

passive emitter rear cell

power purchase agreement

Public Service Company of New Mexico

photovoltaic

research and development

renewable energy

quarter

quarter-over-quarter

renewable energy

rest of world

renewable portfolio standards

Standard and Poor's

Solar Energy Industries Association

Solar Energy Technologies Office

solar renewable energy certificate

third-party owner

utility-scale PV

venture capital and private equity

watt

year-over-year 